\title{
Deep silicon maxima in the stratified oligotrophic Mediterranean Sea
}

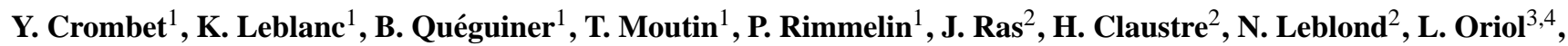 \\ and M. Pujo-Pay ${ }^{3,4}$ \\ ${ }^{1}$ INSU/CNRS, Université d'Aix-Marseille, LOPB-UMR 6535, Laboratoire d'Océanographie Physique et Biogéochimique, \\ OSU/Centre d'Océanologie de Marseille, UMR 6535, Campus de Luminy Case 901, 163 Avenue de Luminy, \\ 13288 Marseille Cedex 09, France \\ ${ }^{2}$ Observatoire Océanologique de Villefranche, Laboratoire d'Océanographie de Villefranche, UMR 7093, \\ Villefranche-sur-mer, France \\ ${ }^{3}$ CNRS, UMR 7621, Laboratoire d'Océanographie Microbienne, Observatoire Océanologique, 66651 Banyuls/mer, France \\ ${ }^{4}$ UPMC Univ Paris 06, UMR 7621, Laboratoire d'Océanographie Microbienne, Observatoire Océanologique, \\ 66651 Banyuls/mer, France
}

Received: 16 July 2010 - Published in Biogeosciences Discuss.: 7 September 2010

Revised: 2 February 2011 - Accepted: 3 February 2011 - Published: 17 February 2011

\begin{abstract}
The silicon biogeochemical cycle has been studied in the Mediterranean Sea during late summer/early autumn 1999 and summer 2008. The distribution of nutrients, particulate carbon and silicon, fucoxanthin (Fuco), and total chlorophyll- $a$ (TChl- $a$ ) were investigated along an eastward gradient of oligotrophy during two cruises (PROSOPE and BOUM) encompassing the entire Mediterranean Sea during the stratified period. At both seasons, surface waters were depleted in nutrients and the nutriclines gradually deepened towards the East, the phosphacline being the deepest in the easternmost Levantine basin. Following the nutriclines, parallel deep maxima of biogenic silica (DSM), fucoxanthin (DFM) and TChl- $a$ (DCM) were evidenced during both seasons with maximal concentrations of $0.45 \mu \mathrm{mol} \mathrm{L}^{-1}$ for BSi, $0.26 \mu \mathrm{g} \mathrm{L}^{-1}$ for Fuco, and $1.70 \mu \mathrm{g} \mathrm{L}^{-1}$ for TChl- $a$, all measured during summer. Contrary to the DCM which was a persistent feature in the Mediterranean Sea, the DSM and DFMs were observed in discrete areas of the Alboran Sea, the Algero-Provencal basin, the Ionian sea and the Levantine basin, indicating that diatoms were able to grow at depth and dominate the DCM under specific conditions. Diatom assemblages were dominated by Chaetoceros spp., Leptocylindrus spp., Pseudonitzschia spp. and the association between large centric diatoms (Hemiaulus hauckii and Rhizosolenia styliformis) and the cyanobacterium Richelia intracellularis
\end{abstract}

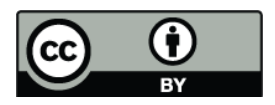

Correspondence to: $\mathrm{Y}$. Crombet (yann.crombet@univmed.fr) was observed at nearly all sites. The diatom's ability to grow at depth is commonly observed in other oligotrophic regions and could play a major role in ecosystem productivity and carbon export to depth. Contrary to the common view that $\mathrm{Si}$ and siliceous phytoplankton are not major components of the Mediterranean biogeochemistry, we suggest here that diatoms, by persisting at depth during the stratified period, could contribute to a large part of the marine primary production as observed in other oligotrophic areas.

\section{Introduction}

Diatoms play an important role in the ocean biological pump and are responsible for an estimated 30\% of the global oceanic primary production (Nelson et al., 1995; Tréguer et al., 1995). This large average value hides wide differences between eutrophic areas, where diatoms contribution to primary production reaches up to $75 \%$ and oligotrophic areas where it scales down to 10-30 \% (Nelson et al., 1995; Uitz et al., 2010). The lowest particulate Si biomass accumulation ever measured has been observed in open ocean oligotrophic gyres, such as in the Sargasso Sea (Nelson et al., 1995; Nelson and Brzezinski, 1997; Krause et al., 2009a). Despite low abundance and chronic Si limitation, diatoms still play a significant role by contributing close to $25 \%$ of annual primary production in both the Sargasso Sea and the Central North Pacific (Brzezinski and Nelson, 1995; Nelson

Published by Copernicus Publications on behalf of the European Geosciences Union. 
and Brzezinski, 1997; Krause et al., 2009a; Brzezinski et al., 1998 ) and representing up to $30 \%$ of the annual carbon export in the Sargasso Sea (Krause et al., 2009b; Nelson and Brzezinski, 1997). Hence, the functioning of these systems shows that despite widespread $\mathrm{N}$ and $\mathrm{P}$ limitation, Si availability is also important to consider and that diatoms may play a crucial role in the biological C pump even in highly oligotrophic regions.

The Mediterranean Sea (MS) is one of the most oligotrophic oceanic systems of the World Ocean (Ryan, 1966; Dugdale, 1976) and is characterised by a longitudinal gradient of oligotrophy increasing eastwards (Azov, 1991) and a near complete $\mathrm{P}$ depletion in the stratified layer during summer and fall, comparable to that observed in open ocean oligotrophic gyres. During the last century, the eastern Mediterranean basin has also become increasingly oligotrophic since the construction of the Assouan dam on the river Nile, whereas the western basin remains well supplied by the Rhône and Po river inputs and entering surface Atlantic waters (Béthoux et al., 1998). This gradient of oligotrophy parallels a gradient of biomass, with an extremely low chlorophyll content in the eastern basin. In a review of the seasonal development of the surface phytoplankton bloom using a ten year archive of SeaWiFS data, D'Ortenzio and Ribera d'Alcala (2009) evidenced distinct regions in the MS with different bloom phasings throughout the year. The main patterns observed over this decadal study were a clear biomass maximum in the western basin in spring with some early starts in November and December, while the eastern basin showed higher Chl- $a$ values during winter and experienced the lowest values during late spring/summer, from May to September. Most of the eastern basin, and parts of the western basin are characterised as "non-bloom" areas which would together cover about $60 \%$ of the MS (D'Ortenzio and Ribera d'Alcala, 2009). However, this study concerns surface Chl- $a$ distribution as observed by satellites and ignores the potential deep phytoplankton accumulation, which we will show in this study, could modulate this clear cut pattern.

Severe oligotrophic conditions appear with the onset of a strong thermal summer stratification in the MS and lead to the development of a Deep Chlorophyll- $a$ Maximum (DCM) closely associated to the nutricline, which has been repeatedly observed across the entire basin and compared to similar structures of the oligotrophic Atlantic and Pacific Ocean (Ediger and Yilmaz, 1996). During summer, primary production rates are usually low, the autotrophic community is dominated by pico- and nanophytoplankton, and the microbial food web becomes predominant under internal nutrient recycling conditions (Thingstad and Rassoulzadegan, 1995). Several studies have documented the limitation of phytoplankton production by nitrogen and phosphorus (Agusti et al., 1998; Béthoux et al., 1992; Krom et al., 1991; Moutin et al., 2002). The MS deep waters are known to have a strong $\mathrm{P}$ deficit, with $\mathrm{N}: \mathrm{P}$ ratios close to 28 , while it is close to 16 in all other oceanic basins (Krom et al., 2004; Pujo-
Pay et al., 2011). A thorough review by Thingstad and Rassoulzadegan (1995) concluded that the Mediterranean planktonic ecosystems experience a general physiological Plimitation but questions still remain on the exact mechanism responsible for the decreased availability of P vs. N. Several hypotheses have been suggested, such as increased $\mathrm{P}$ adsorption onto dust particles, increased $\mathrm{N}_{2}$ fixation by both benthic and pelagic organisms or dystrophic atmospheric and riverine inputs (Krom et al., 2004, 2010) but none has yet been widely accepted as the sole responsible factor for the anomalous $\mathrm{N}: \mathrm{P}$ ratios in the MS. High $\mathrm{N}_{2}$-fixation rates have been previously measured in the Ligurian Sea (Garcia et al., 2006) but other measurements carried out in the MS reported negligible fluxes (Krom et al., 2010; Ibello et al., 2010). Diazotrophic organisms such as the filamentous cyanobacterium Trichodesmium and the symbiotic associations between the cyanobacterium Richelia intracellularis and diverse diatom species have never been reported in abundance in the MS and should play an insignificant role in nitrogen fixation according to Krom et al. (2010). However, a recent review of plankton in the MS evidences the presence of large diatom accumulations at depth during summer (Siokou-Frangou et al., 2010). Our results shed new light on this debate and seem to confirm the latter hypothesis.

While the focus has been placed on the $\mathrm{N}$ and $\mathrm{P}$ cycles, the Si cycle remains poorly investigated in the MS, and the potential contribution of diatoms to primary production and export in the open basins of the MS is similarly poorly constrained while data are mainly available for coastal and near shore areas. This paper presents a comparative study of the dissolved $\mathrm{Si}$ and siliceous phytoplankton distribution patterns over a vast oligotrophic gradient covering the entire MS during summer and fall. The results presented in this paper originate from two cruises that were carried out almost a decade apart over very similar longitudinal gradients and sampling strategies. Vertical distributions of nutrients, biogenic silica, main and accessory pigments (Chl- $a$ and fucoxanthin) as well as particulate organic carbon are presented for the PROSOPE cruise (Productivity of Oceanic Pelagic Systems) and the BOUM cruise (Biogeochemistry from the Oligotrophic to the Ultra-oligotrophic Mediterranean) conducted in fall 1999 and summer 2008 respectively. The objectives of this article are to document the dissolved and particulate $\mathrm{Si}$ cycle and assess diatoms contribution to phytoplankton community as well as their link to $\mathrm{N}_{2}$ fixation, over both the western and eastern Mediterranean basins during the seasonal stratification period. Interestingly, a deep silica maximum was recurrently observed closely associated to the well identified DCM and we will explore the potential formation mechanisms and ecological role of this "deep glass forest" in the Mediterranean Sea. 


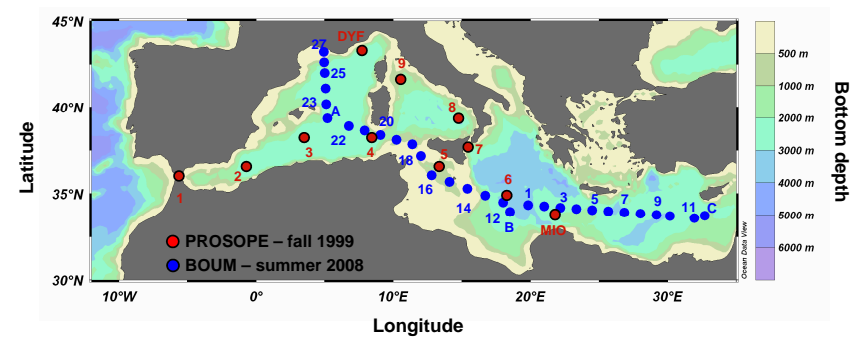

Fig. 1. Cruise tracks and sampling sites during the PROSOPE cruise in late summer/fall 1999 (red dots) and during the BOUM cruises in summer 2008 (blue dots).

\section{Methods}

\subsection{Study areas and sampling strategies}

Seawater samples were collected during two cruises conducted in the western and eastern basins separated by the Sicily strait (Fig. 1). The CNRS/INSU PROSOPE (Productivity of Oceanic Pelagic Systems) cruise was part of the JGOFS (Joint Global Ocean Flux Study) program and was carried out in 1999 during late summer-early autumn (4 September to 4 October) on board R. V. Thalassa. The CNRS/INSU BOUM cruise (Biogeochemistry from the Oligotrophic to the Ultra oligotrophic Mediterranean Sea) was part of the SESAME (Southern Europeans Seas: Assessing and Modelling Ecosystem Changes) integrated project supported by the European Commission, and was conducted in 2008 during summer (20 June to 22 July) on board R. V. L'Atalante. During the PROSOPE cruise, hydrological, biological and chemical parameters were studied at 9 short-term stations and 2 long-term (5 days) process study sites (DYF and MIO located in the Ligurian and Ionian Sea respectively). During the BOUM cruise, hydrological, biological and chemical parameters were studied at 27 shortterm stations and 3 long-term (4 days) process study sites (A, B, C, respectively located in the Algero-Provencal, the Tyrrhenian, and the Levantine basins) located in the center of anticyclonic gyres, where lateral advection was expected to be minimum.

\subsection{Dissolved and particulate matter analysis}

Seawater samples were collected at selected depths between the surface and $200 \mathrm{~m}$ depth with $12 \mathrm{~L}$ Niskin bottles mounted on a seabird CTDO rosette sampler (model SBE 911). Nitrate $\left(\mathrm{NO}_{3}\right)$ and phosphate $\left(\mathrm{PO}_{4}\right)$ were determined by standard automated colorimetric methods on a Bran \& Luebbe Technicon autoanalyzer (Tréguer and Le Corre, 1975) without filtration (nutrients analyses detailed in Pujo-pay et al., 2011). The detection limits were respectively $30 \mathrm{nM}$, and $20 \mathrm{nM}$ for $\mathrm{NO}_{3}$, and $\mathrm{PO}_{4}$. For orthosilicic acid $\left(\mathrm{H}_{4} \mathrm{SiO}_{4}\right), 20 \mathrm{~mL}$ of seawater collected from each Niskin bot- tle were filtered onto $0.2 \mu \mathrm{m}$ polycarbonate filters and analysed for $\mathrm{H}_{4} \mathrm{SiO}_{4}$ according to the colorimetric method of Mullin and Riley (1962) adapted by Strickland and Parsons (1972), with a detection limit of $50 \mathrm{nM}$ and a precision of $\pm 35 \mathrm{nM}$.

For particulate biogenic silica (BSi) analyses, 1 to $2.3 \mathrm{~L}$ of seawater were filtered onto $47 \mathrm{~mm} 0.6 \mu \mathrm{m}$ pore size polycarbonate filters. Filters were folded and stored in plastic Petri dishes, oven dried $\left(60^{\circ} \mathrm{C}\right)$ for $24 \mathrm{~h}$ and stored at room temperature until processing at the laboratory. Filters were then analysed for $\mathrm{BSi}$ following the hot $\mathrm{NaOH}$ digestion technique described by Nelson et al. (1989). The detection limit was $0.011 \mu \mathrm{mol} \mathrm{L}-1$.

For pigment analyses $2 \mathrm{~L}$ of seawater were filtered onto pre-combusted Whatman GF/F $25 \mathrm{~mm}$ filters and stored in liquid nitrogen until processing. Extraction was achieved in $3 \mathrm{~mL} 100 \%$ methanol, followed by a sonication and another filtration on a new GF/F filter to clarify the extracts. Pigments were then analysed by HPLC (High Performance Liquid Chromatography) following the method of Vidussi et al. (1996) (PROSOPE cruise) and Ras et al. (2008) (BOUM cruise). In this paper we only present the distributions of total Chlorophyll- $a$ (TChl- $a$ ) and fucoxanthin (Fuco), the former including Chlorophyll- $a$ and divinyl-Chlorophyll- $a$, the latter being often used as a diagnostic pigment for diatoms (Vidussi et al., 2000). The limit of detection for TChl- $a$ and Fuco were $2.4 \mathrm{ng} \mathrm{L}^{-1}$ for the PROSOPE cruise (Claustre et al., 2004) and better than $0.2 \mathrm{ng} \mathrm{L}^{-1}$ for the BOUM cruise (see (Hooker et al., 2009) for the performances of the Ras et al. (2008) method).

Particulate Organic Carbon (POC) samples were collected by gentle filtration of $1.2 \mathrm{~L}$ for the PROSOPE cruise and $3 \mathrm{~L}$ for the BOUM cruise of seawater on precombusted $\left(450^{\circ} \mathrm{C}\right.$ for $24 \mathrm{~h}$ ) Whatman $\mathrm{GF} / \mathrm{F}$ filters ( $25 \mathrm{~mm}$ in diameter). After filtration, filters were immediately placed in $25 \mathrm{~mL}$ Pyrex bottles (Duran Schott) fitted with screwcap equipped with Teflon ring and dried in an oven at $50{ }^{\circ} \mathrm{C}$ and stored in a dessicator until analyses at the laboratory. POC was determined according to the wet oxydation procedure described by Raimbault et al. (1999) for the PROSOPE samples, and on an elemental CHN analyser Perkin Elmer 2400 for the BOUM samples.

\subsection{Determination of euphotic zone depth $\left(Z_{\mathrm{eu}}\right)$}

The depth of the euphotic zone was determined with a biooptical model for light propagation designed by Morel and Maritorena (2001) where $Z_{\mathrm{eu}}$ is calculated from Chl- $a$ vertical profiles and $K_{d}$ (downward irradiance).

\subsection{Phytoplankton cell counts}

From each Niskin bottle, $0.5 \mathrm{~L}$ seawater were immediately fixed by adding Lugol solution and stored at $4{ }^{\circ} \mathrm{C}$ in the dark until analysis. In the laboratory, subsamples of $50-100 \mathrm{~mL}$ 


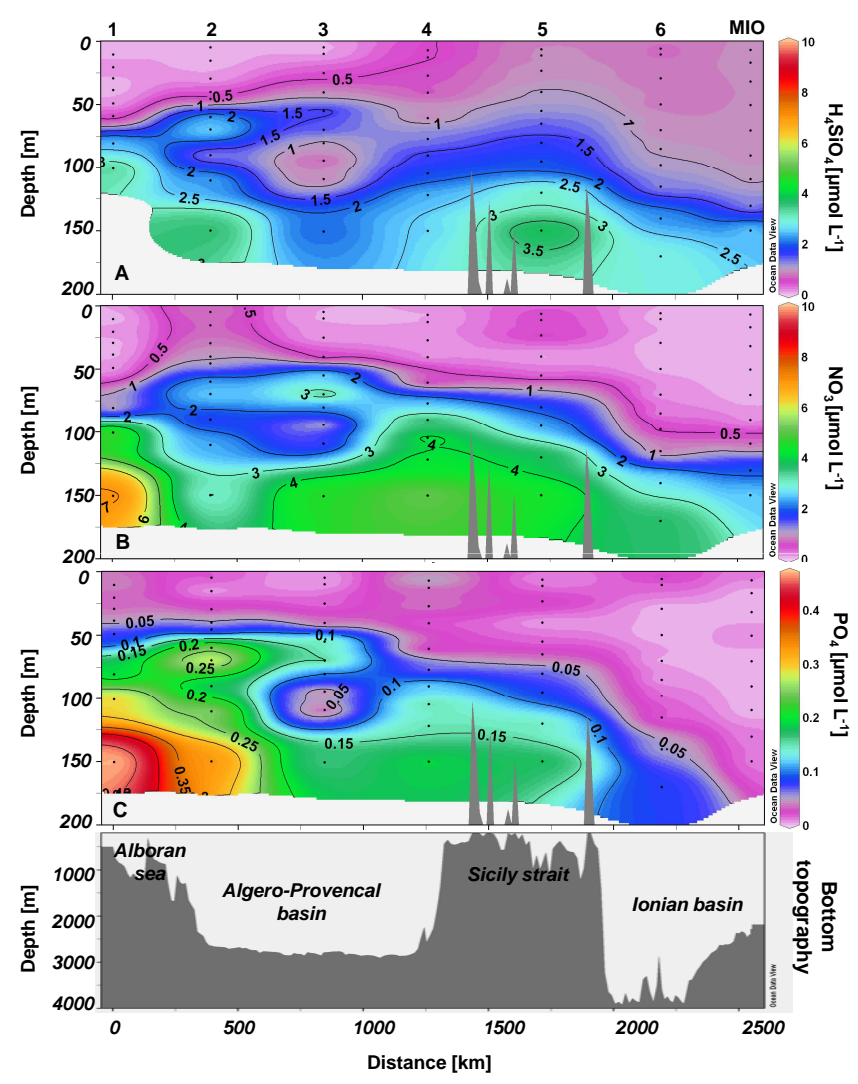

Fig. 2. Nutrient distributions $(\mu \mathrm{M})$ along the transect 1 during PROSOPE the cruise (summer/fall 1999).

were allowed to settle $(48 \mathrm{~h})$ in composite chambers. The cells were identified and counted by using an inverted microscope following the Utermöhl method (Utermöhl, 1931).

\section{Results}

\subsection{Nutrient distributions}

\subsubsection{Large-scale nutrient distribution during the PROSOPE cruise (late summer-early autumn)}

For the sake of clarity, we have presented the data acquired during PROSOPE as two different transects: a longitudinal transect 1 from station 1 to station 6 (Fig. 2) and a meridian transect 2 from station DYF to station MIO (Fig. 3), partially overlapping at stations 6 and MIO. Surface waters were depleted in $\mathrm{H}_{4} \mathrm{SiO}_{4}$ with concentrations below $1 \mu \mathrm{m}$ except at the northern DYF station of transect 2 where the surface concentration reached $1.31 \mu \mathrm{m}$ (Figs. $2 \mathrm{a}$ and $3 \mathrm{a}$ ). On transect 1, the Alboran Sea, characterised by the low surface salinity signature of entering Modified Atlantic Waters (MAW) (Perkins et al., 1990), exhibited low $\mathrm{H}_{4} \mathrm{SiO}_{4}$ concentrations $(<0.5 \mu \mathrm{M})$ in the upper $50 \mathrm{~m}$ at station 1 , and at shallower depths at stations $2(30 \mathrm{~m})$ and $3(10 \mathrm{~m})$. Surface

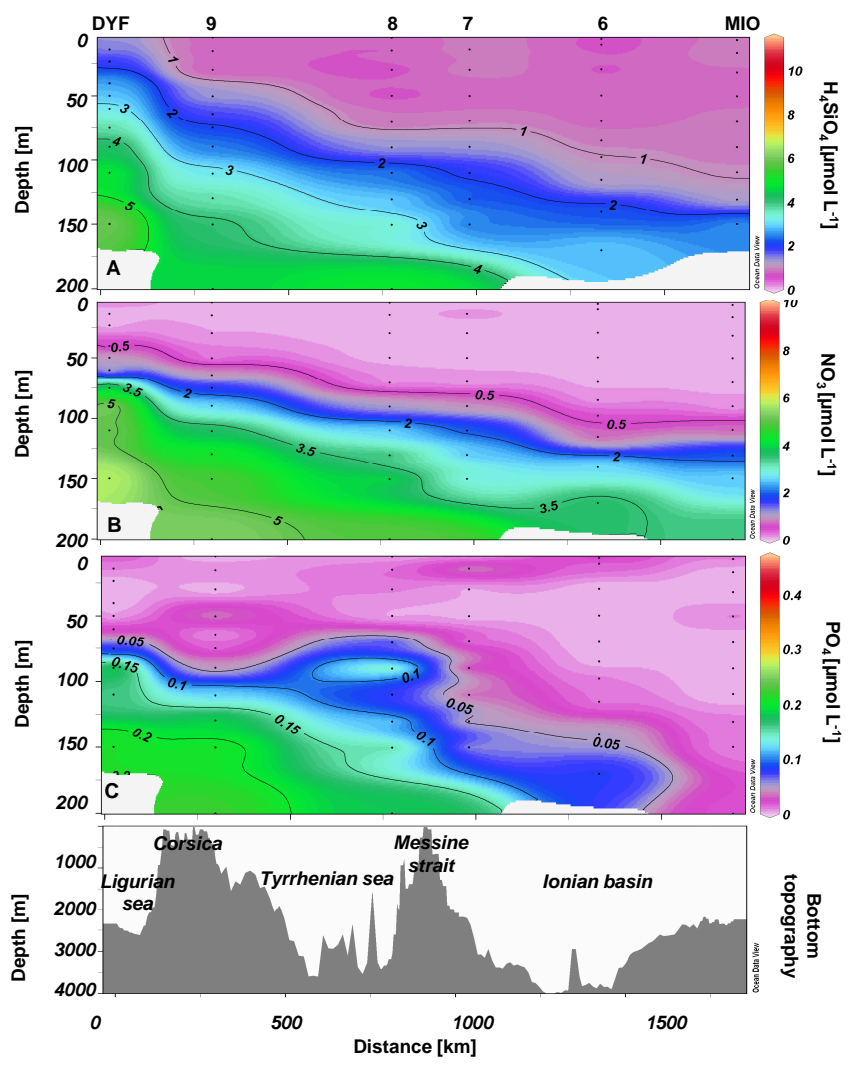

Fig. 3. Nutrient distributions $(\mu \mathrm{M})$ along the transect 2 during PROSOPE the cruise (summer/fall 1999).

$\mathrm{H}_{4} \mathrm{SiO}_{4}$ concentrations then increased along the longitudinal gradient reaching between $0.48-0.88 \mu \mathrm{m}$ at stations 5,6 , and MIO. On transect 1, station 3 and to a lesser extent stations 2 and 4 were characterised by $\mathrm{H}_{4} \mathrm{SiO}_{4}$ minimum between 80 and $110 \mathrm{~m}$. As a general pattern, the $1 \mu \mathrm{M} \mathrm{H}_{4} \mathrm{SiO}_{4}$ isopleth marked the beginning of the silicicline and deepened towards the East, from $\sim 65 \mathrm{~m}$ (station 1 ) and $\sim 40 \mathrm{~m}$ (station 9) to $\sim 110 \mathrm{~m}$ (MIO), although undulations characteristic of the strong mesoscale dynamics of the Algerian Current were clearly visible on transect 1 (Fig. 2). The highest $\mathrm{H}_{4} \mathrm{SiO}_{4}$ concentrations (3.6 to $5.8 \mu \mathrm{M}$ ) were observed in stations 8 , 9, and DYF at $150 \mathrm{~m}$ (Fig. 3a).

$\mathrm{NO}_{3}$ and $\mathrm{PO}_{4}$ distributions (Fig. $2 \mathrm{~b}-\mathrm{c}$ and Fig. 3b-c, respectively) followed the same general pattern of surface water depletion, and a more severe oligotrophy at the eastern stations (6 and MIO). Similarly to $\mathrm{H}_{4} \mathrm{SiO}_{4}, \mathrm{NO}_{3}$ and $\mathrm{PO}_{4}$ varied at depth at station 3 probably also due to mesoscale activity of the Algerian current. Both the nitracline (starting around $0.5 \mu \mathrm{MNO}_{3}$ ) and the phosphacline (starting around $0.05 \mu \mathrm{M} \mathrm{PO}_{4}$ ) deepened progressively towards the East but the phosphacline deepening was much steeper. The largest difference was observed at MIO station where the phosphacline was $100 \mathrm{~m}$ deeper than the nitracline. Contrary to what was observed for $\mathrm{H}_{4} \mathrm{SiO}_{4}$, the highest concentrations of $\mathrm{NO}_{3}$ 


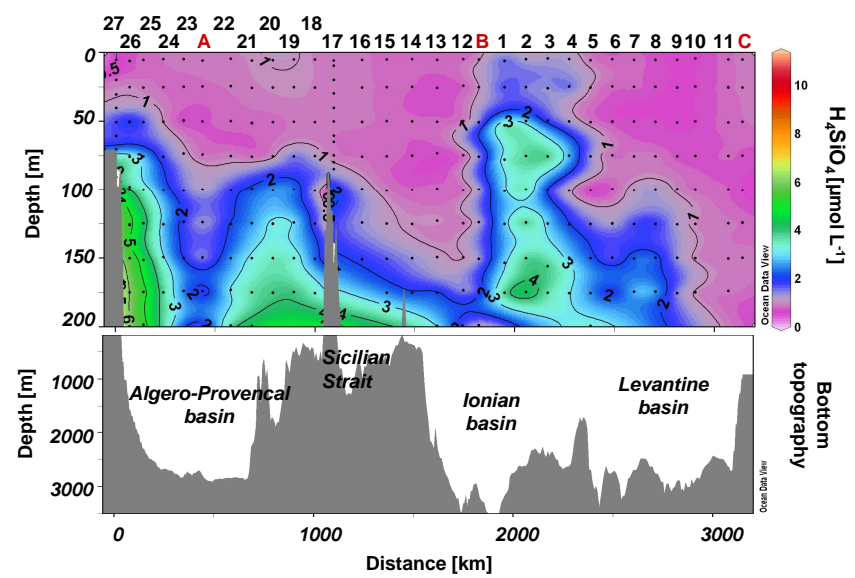

Fig. 4. Orthosilicic acid distribution $(\mu \mathrm{M})$ during the BOUM cruise (late summer 2008).

and $\mathrm{PO}_{4}$ were observed at the entrance of the Gibraltar Strait at station $1\left(7.16 \mu \mathrm{m} \mathrm{NO} 3\right.$ and $0.47 \mu \mathrm{m} \mathrm{PO}_{4}$ at $\left.150 \mathrm{~m}\right)$.

\subsubsection{Large-scale orthosilicic acid distribution during the BOUM cruise (summer)}

In this section, we only describe the $\mathrm{H}_{4} \mathrm{SiO}_{4}$ concentrations (Fig. 4) as $\mathrm{NO}_{3}$ and $\mathrm{PO}_{4}$ distributions are described extensively in Pujo-pay et al. (2011). The BOUM cruise allowed us to extend the observations to the Levantine Basin and thus obtain a complete picture of the zonal gradient of oligotrophy in summer.

The highest $\mathrm{H}_{4} \mathrm{SiO}_{4}$ concentrations were measured at stations 25 and 26 at $175 \mathrm{~m}$, respectively reaching 5.86 and $5.83 \mu \mathrm{m}$ (Fig. 4). The general pattern of $\mathrm{H}_{4} \mathrm{SiO}_{4}$ distribution was again characterised by a general depletion of surface waters and a deepening of the silicicline marked by the $1 \mu \mathrm{m}$ isopleth, from $\sim 25-40 \mathrm{~m}$ in the Ligurian basin (stations 26 and 27) to $\sim 150 \mathrm{~m}$ at the entrance of the Ionian basin (station 12), to finally $>200 \mathrm{~m}$ on the easternmost side of the Levantine basin (stations 11 and C). This general pattern is disrupted in the transition zone between the Ionian and Levantine basins. We observed indeed a substantial enrichment of surface waters, from stations $\mathrm{B}$ to 5 , with highest $\mathrm{H}_{4} \mathrm{SiO}_{4}$ at station 2 .

$\mathrm{NO}_{3}$ and $\mathrm{PO}_{4}$ distributions paralleled that of $\mathrm{H}_{4} \mathrm{SiO}_{4}$ (Figures in Pujo-Pay et al., 2011). $\mathrm{NO}_{3}$ concentrations ranged between the detection limit and $9.23 \mu \mathrm{m}$ (station 25, $200 \mathrm{~m}$ ) whereas $\mathrm{PO}_{4}$ concentrations ranged between the detection limit and $0.37 \mu \mathrm{m}$ (station 26, $200 \mathrm{~m}$ ). Surface waters were depleted for both $\mathrm{NO}_{3}$ and $\mathrm{PO}_{4}$. The nitracline was close to the thermocline whereas the phosphacline was generally located deeper.

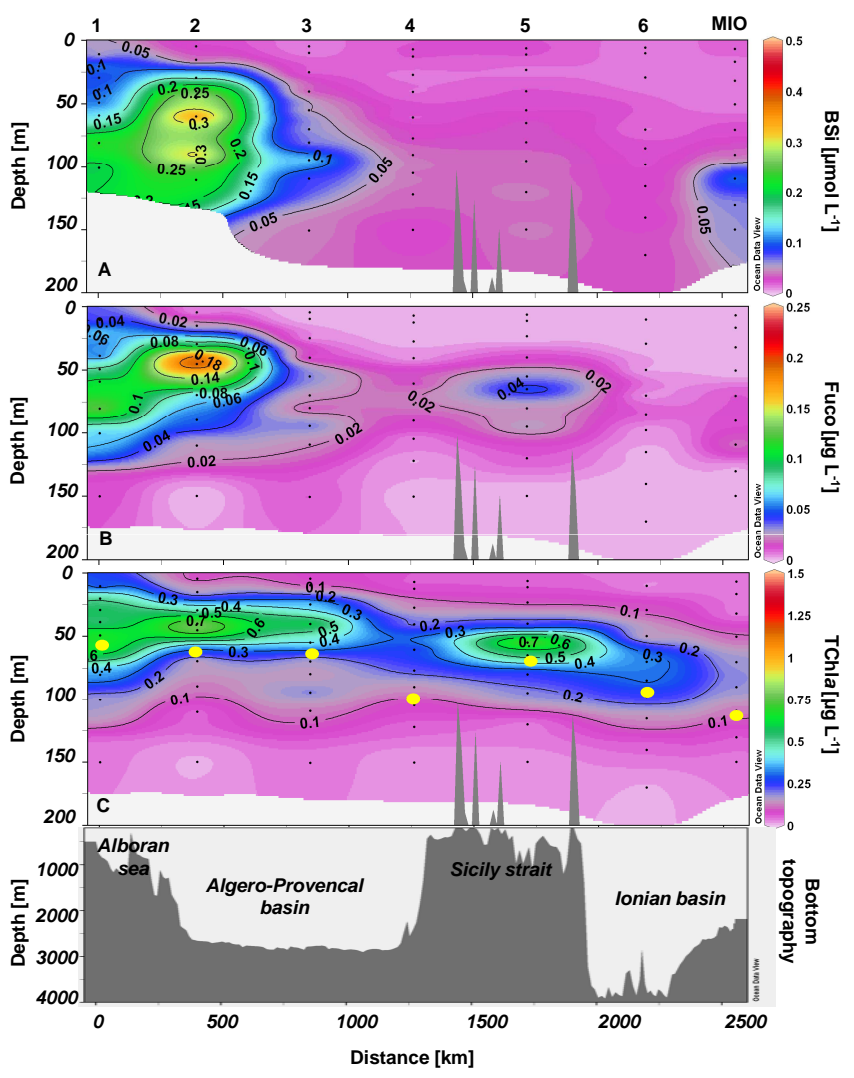

Fig. 5. Distribution of (A) Biogenic Silica (BSi) $(\mu \mathrm{mol} \mathrm{L}-1)$, (B) Fucoxanthin (Fuco) $\left(\mu \mathrm{g} \mathrm{L}^{-1}\right)$, and (C) Total chlorophyll- $a$ (TChla) $\left(\mu \mathrm{g} \mathrm{L}^{-1}\right)$ and depth $(\mathrm{m})$ of the euphotic zone (yellow dots) along transect 1 during the PROSOPE cruise (summer/fall 1999).

\subsection{Particulate matter distribution}

\subsubsection{Large-scale distribution of biogenic silica and associated parameters during the PROSOPE cruise (late summer-early autumn)}

In general, the Mediterranean waters had extremely low $\mathrm{BSi}$ contents in the surface waters, quite uniformly $<0.05 \mu \mathrm{mol} \mathrm{L}{ }^{-1}$, except in the Alboran Sea where concentrations reached up to $0.38 \mu \mathrm{mol} \mathrm{L}-1$ in a deep silica maximum (DSM) located between 60 and $95 \mathrm{~m}$ from station 1 to 3 (Figs. 5a and 6a). Another slight DSM was apparent at DYF station $\left(>0.05 \mu \mathrm{mol} \mathrm{L}^{-1}\right.$ at $\left.75 \mathrm{~m}\right)$ while a more pronounced feature was observed at MIO station (up to $0.11 \mu \mathrm{mol} \mathrm{L}^{-1}$ at $110 \mathrm{~m})$.

Fucoxanthin concentrations ranged from below the detection limit to $0.22 \mu \mathrm{g} \mathrm{L}^{-1}$ (Fig. 5b and 6b). Its distribution was very similar to that of $\mathrm{BSi}$, with low values at the surface, and deep maxima at stations 1, 2, 3, MIO, and DYF coinciding with the observed DSM. The highest Fuco concentration was measured at station 2 with $0.22 \mu \mathrm{g} \mathrm{L}^{-1}$ at $45 \mathrm{~m}$, slightly above the depth of BSi maximum. Another small 


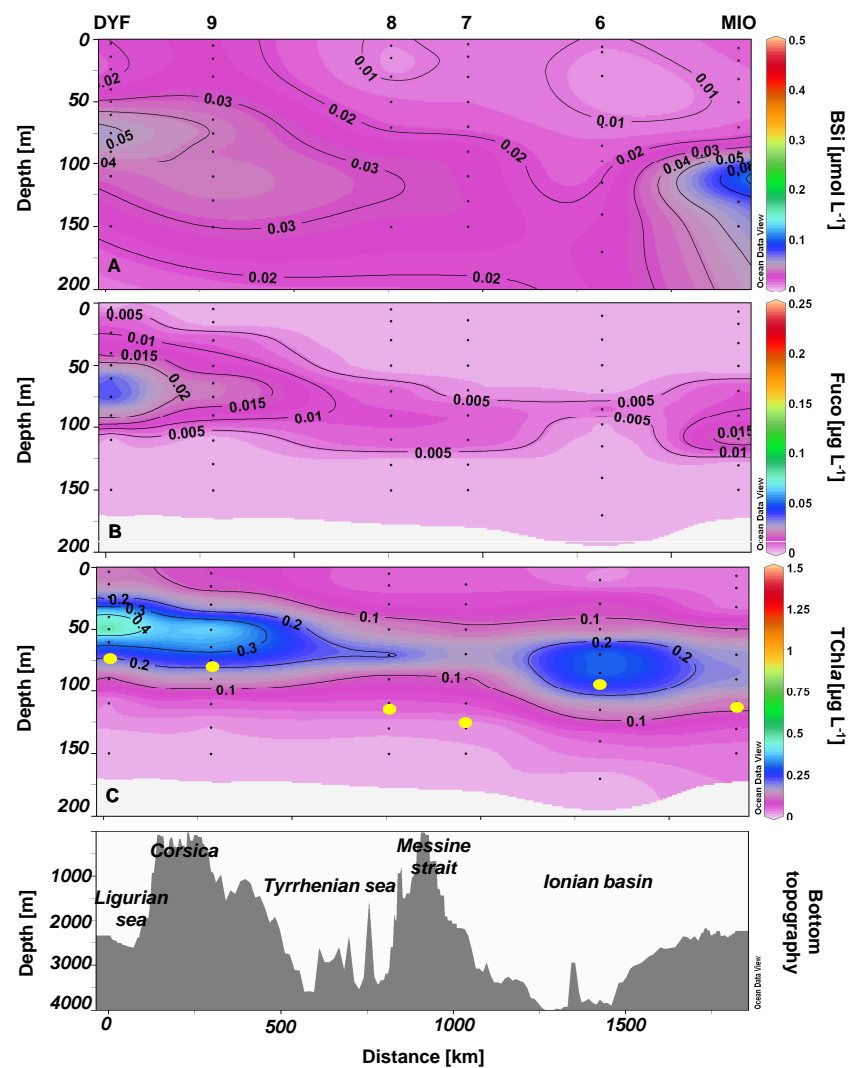

Fig. 6. Distribution of (A) Biogenic silica $(\mathrm{BSi})\left(\mu \mathrm{mol} \mathrm{L}{ }^{-1}\right),(\mathbf{B})$ Fucoxanthin (Fuco) $\left(\mu \mathrm{g} \mathrm{L}^{-1}\right)$, and (C) Total chlorophyll- $a$ (TChla) $\left(\mu \mathrm{g} \mathrm{L}^{-1}\right)$ and depth $(\mathrm{m})$ of the euphotic zone (yellow dots) along transect 2 during the PROSOPE cruise (summer/fall 1999).

deep maximum of Fuco $\left(0.06 \mu \mathrm{g} \mathrm{L}{ }^{-1}\right)$ was observed at station 5 at $65 \mathrm{~m}$, but did not match any BSi increase. This discrepancy could be related to the presence of other nonsiliceous algae containing fucoxanthin such as prymnesiophytes or chrysophytes.

TChl- $a$ concentrations ranged from below the detection limit to a maximum value of $0.96 \mu \mathrm{g} \mathrm{L}^{-1}$ (Figs. 5c and 6c). TChl- $a$ concentrations were generally higher on transect 1 (Fig. 5c) than on transect 2 (Fig. 6c) and maximum concentrations (from 0.4 to $0.9 \mu \mathrm{g} \mathrm{L}^{-1}$ ) were found between 40 and $60 \mathrm{~m}$ at stations 1, 2, 3 and 5. TChl- $a$ exhibited the same pattern of distribution as BSi and Fuco, i.e. a deep TChl$a$ maximum (DCM) present on both transects and deepening eastwards (from 40 to $60 \mathrm{~m}$ at the Gibraltar Strait and in the Ligurian Sea to $\sim 90 \mathrm{~m}$ in the Ionian basin). Unlike the patchy distribution of BSi and Fuco, the DCM appeared as a more regular feature all along the two transects.

Considering the euphotic zone, the DCM and DSM were generally observed $15-30 \mathrm{~m}$ above $Z_{\text {eu }}$ (Figs. 5c and 6c). However DSMs at DYF $(75 \mathrm{~m})$ and MIO $(110 \mathrm{~m})$ were located at the edge of the euphotic zone. In general, the eastward deepening of the deep particulate matter maxima seemed to follow the deepening of the euphotic zone.

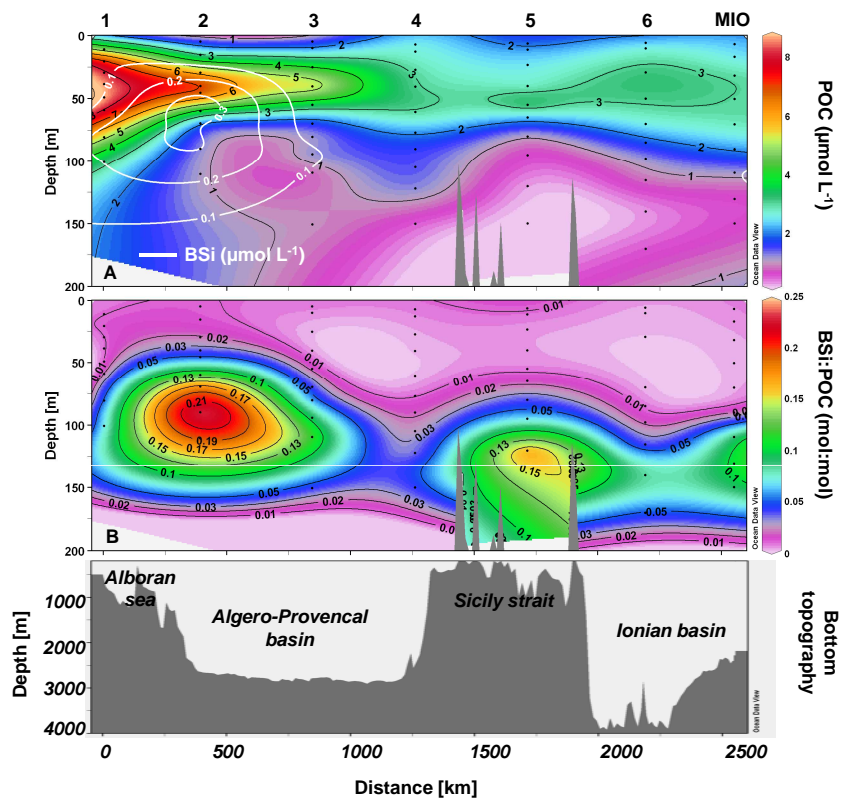

Fig. 7. (A) Distribution of particulate organic carbon (POC) $(\mu \mathrm{mol} \mathrm{L}-1)$, with BSi concentrations $\left(\mu \mathrm{mol} \mathrm{L}^{-1}\right)$ isopleths as overlays in white and (B) BSi:POC ratios (mol:mol) along transect 1 during the PROSOPE cruise (summer/fall 1999).

The distribution of particulate organic carbon is presented together with BSi:POC ratios in Figs. 7 and 8. POC distribution revealed a very similar pattern compared to TChl- $a$ with maximum concentrations found in the Alboran Sea at $50 \mathrm{~m}$ $\left(7 \mu \mathrm{mol} \mathrm{L}{ }^{-1}\right)$, spreading in the Algero-Provencal0 basin at depth, and a new increase in the Ionian basin between stations 5 and MIO, reaching $3 \mu \mathrm{mol} \mathrm{L}{ }^{-1}$. POC was very low below $100 \mathrm{~m}\left(<1 \mu \mathrm{mol} \mathrm{L}^{-1}\right)$ except at site 1 , where moderate concentrations were measured at $150 \mathrm{~m}$ (Fig. 7a). BSi:POC ratios were quite elevated, by comparison to the Brzezinski (1985) ratios, in the Alboran Sea (0.25 at station 2 at $90 \mathrm{~m})$ and over the Sicily Strait ( 0.19 at station 5 at $120 \mathrm{~m}$; Fig. $7 \mathrm{~b}$ ). A third increase was observed at the MIO station, where $\mathrm{BSi}$ POC ratio reached 0.11 at $130 \mathrm{~m}$. On the second transect, POC distribution was quite monotonous (Fig. 8a), with a small subsurface maximum spreading from the DYF station to the MIO station without much decrease at depth. Surprisingly, a subsurface maximum was observed at station 7 between 10 and $50 \mathrm{~m}$ ( 4.6 to $\left.5.5 \mu \mathrm{mol} \mathrm{L}^{-1}\right)$ which did not match any increase in Chl- $a$, Fuco or BSi, and could reflect the presence of heterotrophs. BSi:POC ratios were low $(<0.01)$ over the entire $0-50 \mathrm{~m}$ layer, but increased at depth and in particular at two locations, at station 9 at $150 \mathrm{~m}(0.10)$ and at station MIO (0.11) as mentioned above (Fig. 8b). 


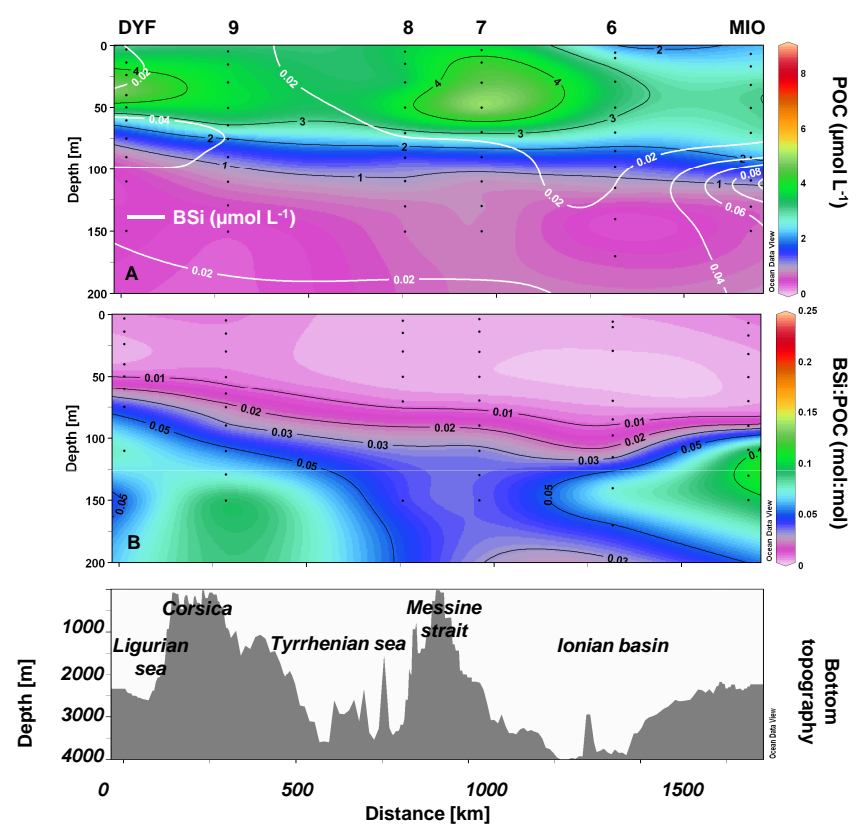

Fig. 8. (A) Distribution of particulate organic carbon (POC) $\left(\mu \mathrm{mol} \mathrm{L} \mathrm{L}^{-1}\right)$, with BSi concentrations $\left(\mu \mathrm{mol} \mathrm{L} \mathrm{L}^{-1}\right)$ isopleths as overlays in white and (B) BSi:POC ratios (mol:mol) along transect 2 during the PROSOPE cruise (summer/fall 1999).

\subsubsection{Large-scale distribution of biogenic silica and associated parameters during the BOUM cruise (summer)}

Surface $(0-50 \mathrm{~m}) \quad \mathrm{BSi}$ concentrations were low $\left(<0.05 \mu \mathrm{mol} \mathrm{L}{ }^{-1}\right)$ throughout the transect except at the coastal station 27 in the Gulf of Lions $\left(0.36 \mu \mathrm{mol} \mathrm{L}^{-1}\right.$ at $5 \mathrm{~m}$ ) (Fig. 9a). A core of slightly higher concentrations (range: $0.05-0.15 \mu \mathrm{mol} \mathrm{L}^{-1}$ ) was observed between $50-175 \mathrm{~m}$ on the continental margin and in the northern Ligurian Sea (stations 23 to 27). However, the most striking feature was the observation of three successive DSM along the transect in a patchy distribution with hot spots of BSi accumulation at depth in discrete areas. The first DSM (up to $0.44 \mu \mathrm{mol} \mathrm{L}^{-1}$ ) was located between the south of Sardinia (station 21) and the Sicilian Strait (station 16) between 50 and $125 \mathrm{~m}$. A second large DSM (up to $0.45 \mu \mathrm{mol} \mathrm{L}^{-1}$ ) was encountered in the Ionian basin (between stations 1 and 9) from 50 to $175 \mathrm{~m}$, while the third DSM (up to $0.24 \mu \mathrm{mol} \mathrm{L}{ }^{-1}$ ) occurred at the eastern end of the transect south of Cyprus in the Levantine basin (station C) at $100 \mathrm{~m}$.

Fuco distribution was in good agreement with BSi since the locations of three successive DFMs closely matched those of the DSM (Fig. 9b). A small increase of Fuco was observed in the northern Ligurian Sea with concentrations reaching up to $0.06 \mu \mathrm{g} \mathrm{L}^{-1}$ at the surface (stations 26 and 27). From station 25 , the Fuco peaks tended to deepen and were always found below $50 \mathrm{~m}$ at all other stations of the

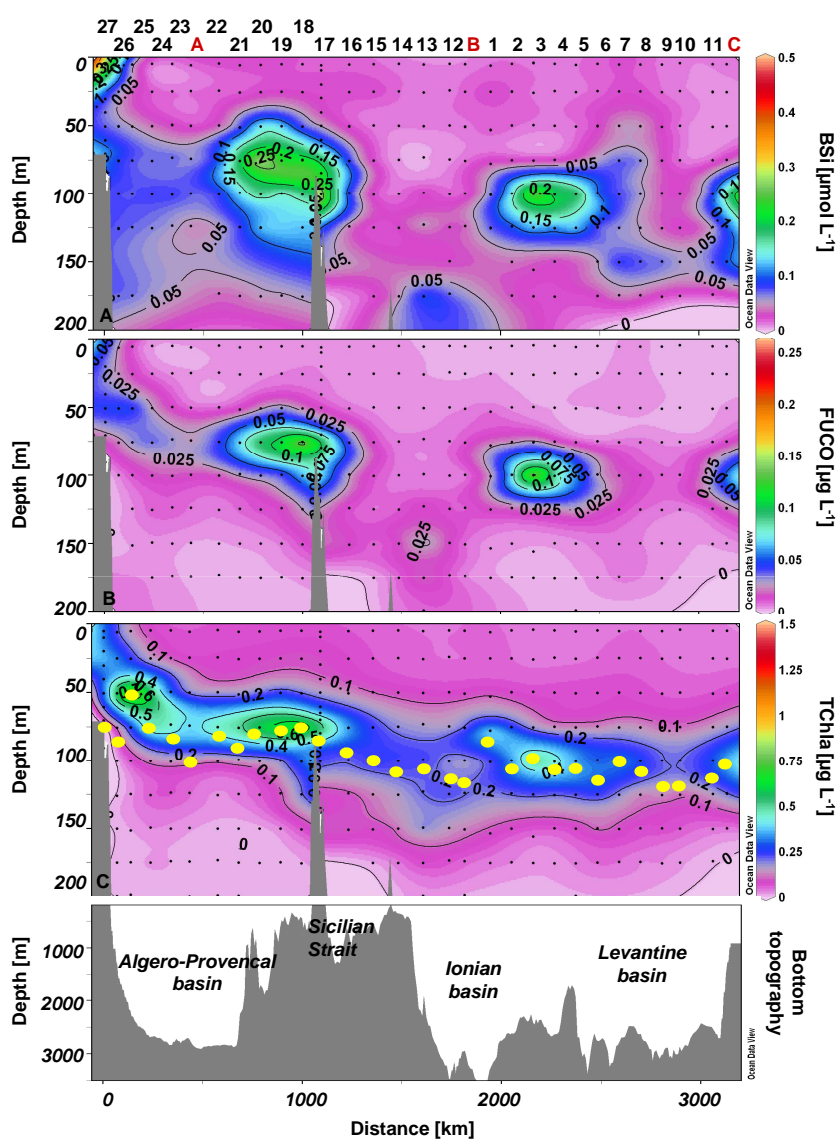

Fig. 9. (A) Distribution of biogenic silica $(\mathrm{BSi})\left(\mu \mathrm{mol} \mathrm{L}{ }^{-1}\right),(\mathbf{B})$ Fucoxanthin (Fuco) $\left(\mu \mathrm{g} \mathrm{L}^{-1}\right)$, and (C) Total chlorophyll- $a$ (TChla) $\left(\mu \mathrm{g} \mathrm{L}^{-1}\right)$ and depth $(\mathrm{m})$ of the euphotic zone (yellow dots) during the BOUM cruise (summer 2008).

transect. The DFM values corresponding to the DSM locations were respectively from West to East of $0.20 \mathrm{\mu g} \mathrm{L}^{-1}$ (station 18), $0.26 \mu \mathrm{g} \mathrm{L}^{-1}$ (station 3) and $0.08 \mu \mathrm{g} \mathrm{L}-1$ (station C). TChl- $a$ followed a very similar pattern but looked like a more continuous feature, as mentioned above for the PROSOPE cruise, with a DCM present at every station (Fig. 9c), except at coastal station 27 where TChl- $a$ showed the highest surface value $\left(0.37 \mu \mathrm{g} \mathrm{L}^{-1}\right)$. Despite the continuous presence of the DCM deepening eastwards, several hot spots with increased concentrations of TChl- $a$ were clearly visible, which locations matched those of the DSM and DFMs. The most important DCM was located in the Ligurian Sea with the highest TChl- $a$ concentration measured $\left(1.70 \mu \mathrm{g} \mathrm{L}^{-1}\right.$ at station $25,50 \mathrm{~m}$ ). Other more pronounced DCMs were detected associated to the main DSM/DFM with $0.87 \mu \mathrm{g} \mathrm{L}^{-1}$ at station $18,0.68 \mu \mathrm{g} \mathrm{L}^{-1}$ at station 3and $0.40 \mu \mathrm{g} \mathrm{L}^{-1}$ at station C.

Finally, the deep structures observed during BOUM appeared more pronounced, showing higher biomass values, than those observed during PROSOPE. Station 3 of the BOUM cruise, geographically very close to MIO station of PROSOPE, is a good example of this trend: 


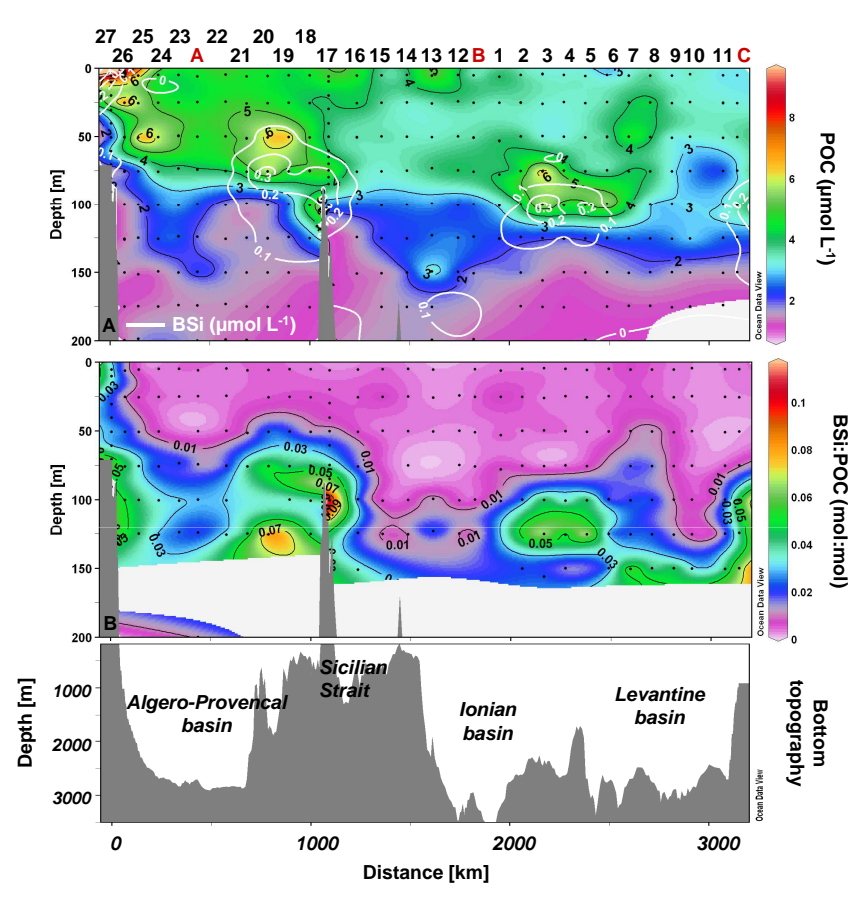

Fig. 10. (A) Distribution of particulate organic carbon (POC) $(\mu \mathrm{mol} \mathrm{L}-1)$, with BSi concentrations $\left(\mu \mathrm{mol} \mathrm{L}^{-1}\right)$ isopleths as overlays in white and (B) BSi:POC ratios (mol:mol) along the BOUM cruise (summer 2008).

maximum BSi concentration was $0.45 \mu \mathrm{mol} \mathrm{L}-1$ at station 3 vs. $0.12 \mu \mathrm{mol} \mathrm{L}^{-1}$ at station MIO; maximum Fuco concentration was $0.26 \mu \mathrm{g} \mathrm{L}^{-1}$ at station 3 vs. $0.02 \mu \mathrm{g} \mathrm{L}^{-1}$ at station MIO and TChl- $a$ highest value was $0.68 \mu \mathrm{g} \mathrm{L}^{-1}$ at station 3 vs. $0.18 \mu \mathrm{g} \mathrm{L}^{-1}$ at station MIO. Hence, the siliceous phytoplankton biomass was generally higher in summer 2008 than in late summer/early autumn 1999.

The depth of the euphotic zone during summer 2008 was approximately the same than late summer/early autumn 1999, and ranged between 50-120 m (Fig. 9c) as during PROSOPE cruise. If the deep maxima still followed the deepening of $Z_{\mathrm{eu}}$, we can note that they were positionned just few meters above the $Z_{\text {eu }}$ and thus lower in the euphotic zone compared to the PROSOPE cruise.

Particulate organic carbon follows the same trends than $\mathrm{BSi}$ and Chl- $a$ with 4 maxima $\left(\sim 6 \mu \mathrm{mol} \mathrm{L}^{-1}\right)$ located in the northern Algero-Provencal basin near the surface, and at depth over the Sicilian strait, in the Ionian Sea and at station $\mathrm{C}$ in the Levantine basin (Fig. 10a). Low BSi:POC ratios $(<0.01)$ were observed from the surface to as deep as $125 \mathrm{~m}$ in the Ionian and Levantine basins, but increased between 100 and $150 \mathrm{~m}$ to more elevated values (0.05 to 0.09$)$ at the three main DSM locations but with a slight offset with depth (Fig. 10b).
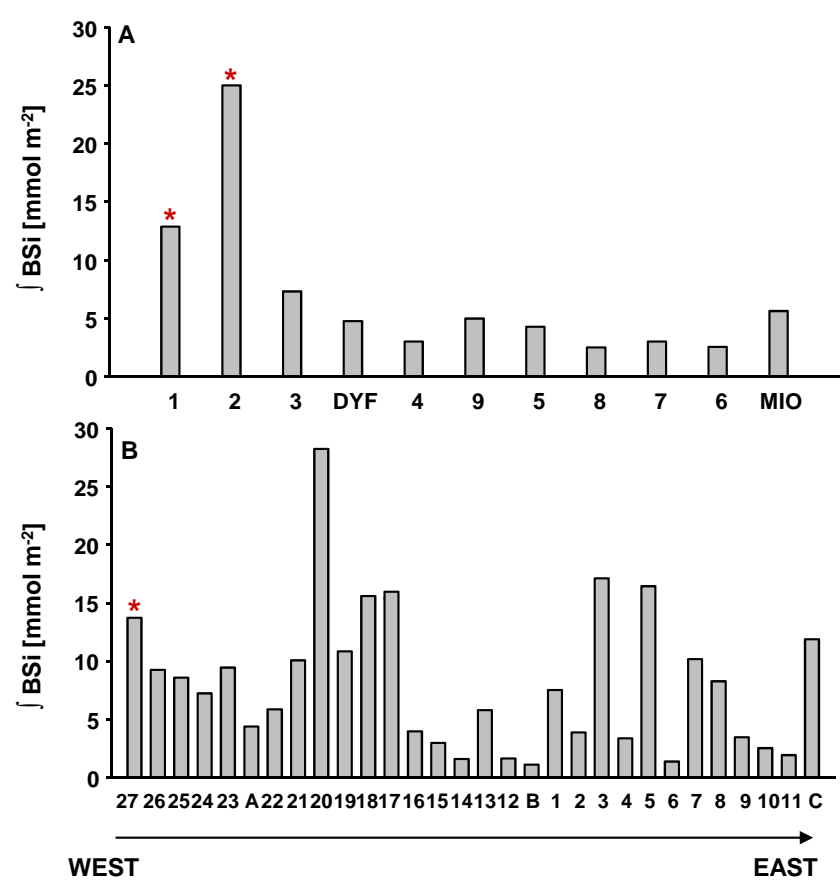

Fig. 11. Integrated biogenic silica stocks $\left(\mathrm{mmol} \mathrm{m}^{-2}\right)$ over 0 $150 \mathrm{~m}$ (with exceptions indicated by a red star) for the PROSOPE cruise (A) and the BOUM cruise (B) along a West-East gradient. Integration depths at PROSOPE stations 1 and 2 were 100 and $110 \mathrm{~m}$ respectively, while integration depths at BOUM stations 17 and 27 were 118 and $100 \mathrm{~m}$ respectively.

\subsection{Integrated BSi stocks}

Integrated $(0-150 \mathrm{~m})$ silicon stocks during both cruises are presented in Fig. 11. During PROSOPE (Fig. 11a), the western basin exhibited the highest BSi stocks which ranged from 2.6 to $25.0 \mathrm{mmol} \mathrm{m}^{-2}$, with the highest stocks at the three westernmost stations (1 to 3 ). Stocks were several folds lower in the eastern basin and ranged from 2.2 to $5.8 \mathrm{mmol} \mathrm{m}^{-2}$. During the BOUM cruise (Fig. 11b), integrated BSi stocks were on average higher despite a similar range of values from 1.1 to $28.2 \mathrm{mmol} \mathrm{m}^{-2}$. Despite some large spatial variability due to the presence of several hot spots of BSi accumulation in both basins, the average BSi stock in the western basin (station 27 to 17) was higher $\left(11.6 \mathrm{mmol} \mathrm{m}^{-2}\right)$ than the average value for the eastern basin $\left(5.8 \mathrm{mmol} \mathrm{m}^{-2}\right)$.

\section{Discussion}

\subsection{Oligotrophic gradient in the Mediterranean Sea}

The gradient of oligotrophy is well documented in the Mediterranean Sea (McGill, 1961; Sournia, 1973; Krom et al., 1991; Moutin and Raimbault, 2002) and is a consequence of the anti-estuarine thermohaline circulation and the 

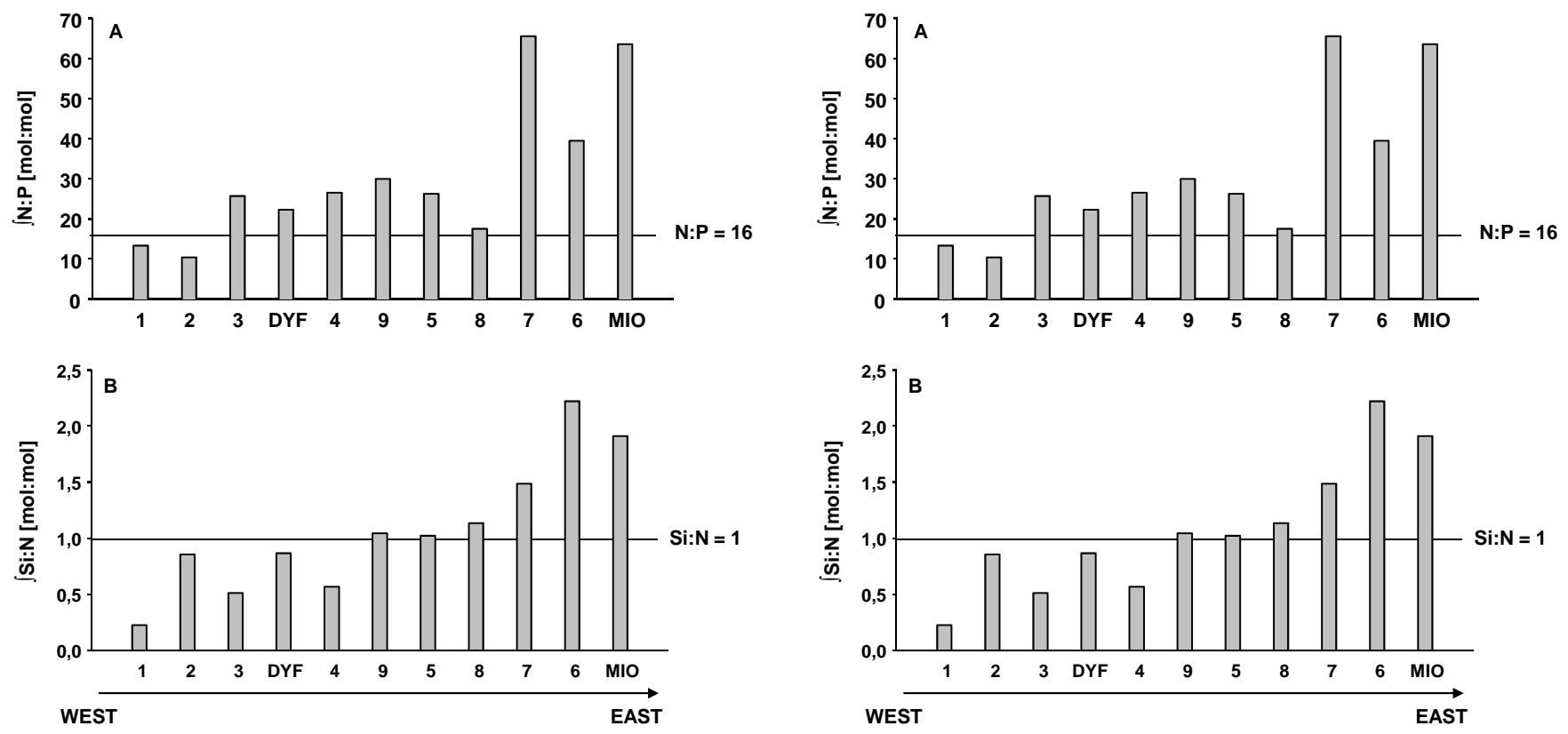

Fig. 12. Integrated $\mathrm{N}: \mathrm{P}(\mathbf{A}))$ and $\mathrm{Si}: \mathrm{N}$ (B) ratios (mol:mol) over $0-150 \mathrm{~m}$ for the PROSOPE cruise along a West-East gradient. Integration made under $150 \mathrm{~m}$ is signified by a red star. Integration at stations 1 and 2 was made over 100 and $110 \mathrm{~m}$ respectively.

nutrient input's asymmetry between the western and the eastern basins. The degree of oligotrophy along this gradient is then determined by the balance between biological processes such as production, remineralisation, and export, and can be locally affected by mesoscale or submesoscale structures like hydrological fronts and eddies (Crise et al., 1999). Accordingly, we observed that surface waters of the Mediterranean Sea were depleted in nutrients during both summer and fall and that all nutriclines deepened towards the East (Figs. 2 to 4). The phosphacline was generally deeper than the nitracline and silicicline in particular in the eastern basin, which could induced a general P limitation in the Ionian and Levantine basins (Pujo-Pay et al., 2011). The P deficit in both surface and deep waters of the Mediterranean Sea is well established but the responsible mechanisms are still a matter of debate (Krom, 1995). Considering the reference N:P ratio of 16 (Redfield et al., 1963), the general P limitation of the Mediterranean Sea is further emphasized by the integrated surface N:P ratios which are generally well $>20$ (Figs. 12a and 13a) except in a few areas such as the Alboran Sea during fall and at only three stations during summer (stations 6 , 14 and $\mathrm{C}$ ). The $\mathrm{P}$ deficit is more intense in the eastern basin during both seasons, with extremely high $\mathrm{N}: \mathrm{P}$ ratios during summer (40-80 and sometimes $>100$ ) when $\mathrm{P}$ is close to the detection limit, and slightly lower ratios during fall in the Ionian sea (40-65), when $\mathrm{N}$ becomes more depleted. Our data are consistent with high ratios usually found in the Mediterranean Sea (around 20-30 in the deep waters and up to 100

Fig. 13. Integrated $\mathrm{N}: \mathrm{P}(\mathbf{A})$ and $\mathrm{Si}: \mathrm{N}$ (B) ratios (mol:mol) over 0 $150 \mathrm{~m}$ for the BOUM cruise along a West-East gradient. Integration made under $150 \mathrm{~m}$ is signified by a red star. Integration was made over $118 \mathrm{~m}$ for station 17 and $100 \mathrm{~m}$ for station 27.

in the surface waters) (McGill, 1969; Jacques and Tréguer, 1986; Moutin and Raimbault, 2002).

If nitrogen and phosphate are usually considered as limiting in the Mediterranean Sea, silicon has been considered for a long time abundant in the euphotic zone (Jacques and Tréguer, 1986; Krom et al., 1993, Tanaka et al., 2011) and often ignored as a potential limiting factor in biogeochemical models (Crispi et al., 2002). Yet, we observed during summer and fall a potential $\mathrm{Si}$ deficit compared to $\mathrm{N}$ in the entire Algero-Provencal basin and as far towards the East as the Tunisian continental shelf located across the Sicily Strait, with integrated $\mathrm{Si}: \mathrm{N}$ ratios $<1$ in the first $150 \mathrm{~m}$ (Figs. 12b and $13 \mathrm{~b}$ ). If we consider the empirical Si:N uptake ratio $\approx 1$ for siliceous phytoplankton (Brzezinski, 1985) Si availability could be limiting for diatom growth. The Si deficiency is relieved in the Ionian and Levantine basins where $\mathrm{Si}: \mathrm{N}$ ratios remain well over 1 during both seasons, but with local minima close to 1 between stations 3 and 8 during BOUM, where a large DSM was observed. Considering the Si:N:P ratios simultaneously, $\mathrm{N}$ and $\mathrm{P}$ constitute the prominent potential limiting factors in the Mediterranean Sea, but Si appears as potentially limiting to diatom growth in the western basin and over the Tunisian continental shelf. Consistent with our findings, Ribera d'Alcala et al. (2003) suggested that diatoms might play an important role in the eastern basin based on basin-scale nutrient estimates. The elevated Si:N ratio in intermediate and deep waters led the authors to the conclusions that diatoms were probably playing an important 
role in the surface layer and that the high $\mathrm{Si}: \mathrm{N}$ ratio at depth evidenced an active vertical transfer of siliceous material. The little attention given to orthosilicic acid distribution in the MS is likely coupled to the idea that the DCM observed during stratified oligotrophic conditions is overall dominated by pico- and nanophytoplankton. Our data show that during both summer and fall, this is not always the case and that diatoms may locally be important contributors to the DCM. We explore tentative explanations for the co-occurrence of the DSM with the DCM in the following paragraphs.

\subsection{Occurrence of a Deep Silica Maximum (DSM) in the Mediterranean Sea}

The data obtained during the BOUM cruise confirmed the recurrence of DSM in the different Mediterranean basins during the stratified oligotrophic period, an observation that was initially made during PROSOPE. DSM were found in the Alboran, Ionian and Ligurian basins during late summer-fall 1999 and were also observed in the Levantine basin and in the Sicilian Strait in summer 2008. Similar characteristics of the DSM during both seasons were a patchy distribution (while the DCM was a more continuous feature across the MS) and a progressive deepening of this structure towards the East, following that of the nutriclines and $Z_{\mathrm{eu}}$. Differences consisted in Chl- $a$ maximum values that were almost twice as high in fall compared to summer despite similar concentration ranges of both $\mathrm{BSi}$ and Fuco, which indicates a lower relative contribution of diatoms to the phytoplankton community later in the season.

The occurrence of DSM has been previously observed in Mediterranean waters (Price et al., 1999a), but it has never been reported to be a recurrent feature of the stratified open Mediterranean Sea. The first reference in the MS goes back two decades ago in a coastal system off the coasts of Egypt close to the Nile River mouth, where AbdelMoati (1990) evidenced the presence of a DSM, closely coupled to the DCM at $100 \mathrm{~m}$ depth, with elevated BSi concentrations $\left(1.35 \pm 0.49 \mu \mathrm{mol} \mathrm{L}{ }^{-1}\right)$. In the Algerian current, Gould and Wiesenburg (1990) observed a narrow band of Chl- $a$ at $54 \mathrm{~m}$ dominated at $98 \%$ by the centric diatom Thalassiosira partheneia. Smaller DSM $\left(\mathrm{BSi}<0.1 \mu \mathrm{mol} \mathrm{L}{ }^{-1}\right)$ were later observed in the Cretan Sea in spring and fall by Price et al. (1999b). Finally, Leblanc et al. (2004) reported a moderate $\mathrm{DSM}\left(\mathrm{BSi}<0.2 \mu \mathrm{mol} \mathrm{L}{ }^{-1}\right)$ during winter in the Almeria-Oran Front inside an anti-cyclonic gyre but which was mainly attributed to lateral advection of a frontal bloom and cross-frontal exchanges of biomass along the isopycnal slopes.

Nonetheless, the DSM is a feature that has been observed in several other oceanic systems worldwide in recent years, in the oligotrophic environment of the Sargasso Sea (Brzezinski and Kosman; 1996, Krause et al., 2009a) and gyres of the Equatorial and Central North Pacific (Blain et al., 1997; Brzezinski et al., 1998; Scharek et al., 1999,
Dore et al., 2008). This feature has also been recurrently observed in the Southern Ocean but with often much higher biogenic silica concentrations (Quéguiner, 2001; Leblanc et al., 2002; Quéguiner and Brzezinski, 2002; Beucher et al., 2004; Mosseri et al., 2008).

\subsection{Deep Chlorophyll-a Maximum (DCM) and potential formation mechanisms}

The DCM is a well known structure in the ocean, ubiquitous in stratified oligotrophic areas and notably in the entire Mediterranean Sea (Berman et al., 1984; Estrada, 1985; Estrada et al., 1993; Ediger and Yilmaz, 1996; Abdel-Moati, 1990; Tselepides et al., 2000; Herut et al., 2000). The DCM formation depends on the equilibrium between phytoplankton accumulation mechanisms (physical gradient, physiological adaptation to light and nutrient limitation, local growth at nutricline depth) and dispersion processes such as sinking, advection, or grazing. If the DCM is sustained for several weeks or months it implies that gain terms (local growth or accumulation from passive sinking at the pycnocline) are balanced with loss terms (grazing and sinking out of the euphotic layer) as described in detail by Parslow et al. (2001) for the Southern Ocean. During the BOUM study, the vertical distribution of small copepods and nauplii closely matched the DCM along the entire transect (Nowaczyk et al., 2011), which is indicative of grazing inside the DCM, which in turn indicates that local growth was occurring to compensate for this loss term and maintain the feature throughout summer. However DCM formation mechanisms in the MS are somewhat different than in the tropics where this feature is generally permanent throughout the year (Mann and Lazier, 1996), while it is mainly seasonal in the MS and likely the result of a transitory state between post hivernal mixing and summer stratification (Estrada et al., 1985, 1993).

\subsection{Correlations between DCM, DSM and DFM in the Mediterranean Sea}

The DSM was not systematically correlated to the DCM but the presence of a DSM was observed at a large majority of stations (83\%) during summer and at about half of the stations (45\%) during fall. However, the more intense DSM were observed over more restricted areas along the cruise tracks.

During late summer/fall 1999 deep maxima were not strictly correlated, especially in the Alboran and Ligurian Seas. Cell counts revealed that the DSM in the Alboran Sea at station $2(30 \mathrm{~m})$ was dominated by Guinardia delicatula (5300 cells $\mathrm{L}^{-1}$ ), Dactyliosolen fragilissimus ( 2780 cells $\left.\mathrm{L}^{-1}\right)$, Leptocylindrus minimus $\left(3530\right.$ cells L $^{-1}$ ) and Leptocylindrus danicus $\left(2840\right.$ cells $\left.\mathrm{L}^{-1}\right)$. At station MIO, the diatom population was dominated by $L$. danicus (590 cells $\mathrm{L}^{-1}$ ) and Pseudo-nitzschia spp. (300 cells L $\mathrm{L}^{-1}$ ), whereas Thalassionema frauenfeldii and Thalassionema 
nitzschioides showed the highest abundance at station DYF. However, silicoflagellates (Dictyocha speculum and Dictyocha octonaria) were more abundant than diatoms at all other depths from 25 to $110 \mathrm{~m}$ at DYF, and probably contributed to a large part to the DSM, which was also the case at stations 8 and 9, despite very low abundances. Diatoms constituting those deep maxima did not seem to be actively photosynthesizing as suggested by the negligible primary production rates measured at these depths (data not shown).

During summer 2008, the DSM, DFM and DCM were always correlated and located at the same depths, deepening towards the East. Cell counts revealed an important number of diatoms at every DSM but with a decreasing eastward trend. Total diatom abundance reached 51700 cellsvL $^{-1}$ at station $20(75 \mathrm{~m}), 36000$ and 28300 cells $\mathrm{L}^{-1}$ respectively at station 3 and $5(100 \mathrm{~m})$, and finally 15500 cells $\mathrm{L}^{1}$ at station $\mathrm{C}(100 \mathrm{~m})$. This surprisingly high numbers of diatoms (between 10000 and 40000 cells $\mathrm{L}^{-1}$ ) have already been reported before in oligotrophic areas (Riley, 1957; Hulburt, 1990) and during the summer blooms at station ALOHA in the Central North Pacific (Dore et al., 2008) and were mainly associated to the dominance by the genus Chaetoceros. The DSM located in the western basin showed a much higher species diversity than the other two DSMs, with a large contribution of pennates such as Pseudo-nitzschia spp. (up to 14000 cells L $^{-1}$ at $75 \mathrm{~m}$ at station 20) but also many other genera such as Bacteriastrum, Leptocylindrus orRhizosolenia. This dominant diatom assemblage is quite similar to the one described in previous syntheses presented by Estrada et al. (1993) and Béthoux et al. (2002a) for the MS. On the other hand, the DSM observed in the eastern basin were much less diverse, and exhibited very few pennate diatoms while Chaetoceros spp. again dominated among the centric species. Silicification, and hence active growth occurred in all the DSM as evidenced by the measured increased uptake of the fluorescent probe PDMPO, which is a proxy for Si production, and a clear indentation in the silicic acid vertical profiles at the same depths (K. Leblanc, personal communication, 2011).

Another moderate DSM was observed at depth on the Tunisian continental slope, which was not associated to a DCM, but to a slight increase of Fuco. Cell counts indicated an increase in diatom abundance at 100 and $125 \mathrm{~m}$ at station 13 in particular, but samples were not taken for microphytoplankton abundance at the DSM depth thus preventing any comparison with the DCM community. However, available data suggest that this DSM likely corresponded to senescent diatoms with low pigment content, probably sinking out of the euphotic layer rather than to an episode of sediment resuspension above the Tunisian continental slope.

An intriguing difference between the two cruises were the similar amounts of BSi in the DSM (maximum concentrations around $0.2-0.35 \mu \mathrm{mol} \mathrm{L}-1$ for both cruises), while diatom cell counts was an order of magnitude higher during BOUM (up to 51700 cells L ${ }^{-1}$ ) than during PROSOPE (up to 5300 cells $\mathrm{L}^{-1}$ ). This difference is most likely due to the presence of different diatom species during summer and fall, with smaller species (belonging to the genera Chaetoceros and Bacteriastrum) dominating during BOUM, while larger species (belonging to the genera Guinardia, Leptocylindrus, Pseudo-nitzschia, and Thalassionema) were observed during PROSOPE. Alternatively, diatoms could be less silicified in summer than later in the season. If diatoms in summer were in a better physiological state and exhibited higher division rates this could lead to lower Si content per cell, because senescent diatoms tend to be more heavily silicified (MartinJézéquel et al., 2000).

As the season progresses to the highest oligotrophic degree in late summer/fall, diatoms forming the DSM seem to maintain themselves deeper following the descent of nutriclines, still at the DCM depth but probably at reduced growth rate and under a more or less senescent state as suggested by the pigment decrease observed at site MIO and DYF, and the higher BSi:POC ratios encountered at the DSM during fall. Despite being prominent in our study, the occurrence of coupled DSM and DFM is not a global feature of the Mediterranean Sea during summer but a very localised phenomenon. This suggests that DSM formation is controlled by complex biotic/abiotic interactions where diatoms could take a temporary advantage of very low light conditions and nutricline oscilations and thus dominate other phytoplankton groups such as nano- and picophytoplankton. To explain the nutrient supply mechanisms into the euphotic zone, several authors demonstrated that formation of cyclonic and modewater eddies and interactions between such mesoscale features could induce sporadic injections directly assimilated by phytoplankton in the euphotic zone, (Falkowski et al., 1991; McGillicuddy and Robinson, 1997; McNeil et al., 1999). These mesoscale events led to great siliceous biomass enhancement at depth as it has been observed in numerous areas, for instance in the Pacific (Benitez-Nelson et al., 2007) or in the Atlantic (McNeil et al., 1999; Steinberg et al., 2001; Conte et al., 2003; McGillicuddy et al., 2007) with the greatest BSi concentrations at BATS related to mesoscale events (Krause et al., 2009a). This has also been reported for the MS by Theodorou et al. (1997) who observed higher BSi contents $(\sim 0.36 \mu \mathrm{mol} \mathrm{L}-1)$ associated to the passage of two cyclonic eddies in the Cretan Sea. Enhanced biological production and chlorophyll accumulation were observed in cyclonic eddies generated by the Algerian current (Moran et al., 2001), while the impact of anticyclonic eddies on biological activity was demonstrated in the same area during the ELISA program (Taupier-Letage et al., 2003). If chlorophyll biomass was generally lower at the center of anticyclonic eddies, the relationship between Chl- $a$, nutrients and eddy structure was found to be highly variable with the season, the age of the eddy, and its location and internal dynamics (Taupier-Letage et al., 2003). In the eastern basin, warm core eddies, and notably the Cyprus anticyclonic eddy (which would correspond to station $\mathrm{C}$ in this study), were found to harbour local 
enhancement of Chl- $a$, attributed to very deep winter mixing within the eddy (Zohary et al., 1998). This is confirmed by the Argo drifting float immerged during BOUM which stayed in the eddy during the following winter and revealed a winter mixing depth down to $400 \mathrm{~m}$ (Moutin et al., 2011). It is likely that the local intense deep diatom blooms are linked to mesoscale features and to eddy formation, although we lack sufficient data to properly explore the different mechanisms at play within cyclonic or anticyclonic eddies and to relate them to the DCM/DSM formation during our study. If the DSM are closely linked to hydrological features, their heterogeneous nature probably led to systematic under sampling as also suggested by Ribera d'Alcala et al. (2003) and Siokou-Frangou et al. (2010) and might explain why they have rarely been reported in the MS.

\subsection{Ecological and biogeochemical implications of the presence of DSM in stratified oligotrophic systems}

During PROSOPE and BOUM cruises, the diatom community was dominated by Chaetoceros spp., Leptocylindrus spp. and Pseudonitzschia spp., which are commonly observed in the Mediterranean DCM (Estrada, 1985; Kimor et al., 1987) but also in other oligotrophic mid-ocean gyres (Blain et al., 1997; Brzezinski et al., 1998; McGillicuddy et al., 2007). However, the potentially symbiotic association between the centric diatoms Hemiaulus hauckii and Rhizosolenia styliformis and the $\mathrm{N}_{2}$ fixing cyanobacterium Richelia intracellularis were also observed during both cruises but in low abundance. During the BOUM cruise, phytoplankton net hauls revealed that they were present at all stations sampled across the entire basin. This association was commonly observed in the world oligotrophic ocean and the MS (Guillard and Kilham, 1978; Ignatiades, 1969) and has already been observed as an important component of the diatom community in the DCM of the North Pacific oligotrophic gyres (Dore et al., 2008 and references there in). The presence of a heterocyst in the cyanobacterium $R$. Intracellularis allows $\mathrm{N}_{2}$ fixation and probably constitutes an ecological advantage for the associated diatom by providing a nitrogen source under N-depleted conditions (Villareal, 1991; Villareal et al., 1999). In the tropical Atlantic, Carpenter et al. (1999) encountered an extensive bloom of H. hauckii and evaluated that in addition to Trichodesmium sp., they could supply up to $25 \%$ of the total $\mathrm{N}$ demand through the water column. In the North Pacific Subtropical Gyre (NPSG) at station ALOHA, Dore et al. (2008) estimated that the highest integrated $\mathrm{N}_{2}$ fixation rates occurred during summer while either Trichodesmium sp. or diatom blooms (mainly constituted by Rhizosolenia sp. or Hemiaulus sp. with R. intracellularis) were observed.

Intense nitrogen fixation by Posidonia spp. mats and planktonic organisms such as Trichodesmium spp. and the diatom-cyanobacteria association have been invoked as one of the reasons that could explain the higher $\mathrm{N}: \mathrm{P}$ ratios in
Mediterranean deep waters (Sachs and Repeta, 1999; Ribera d'Alcala et al., 2003) but this assertion remains to be substantiated (Béthoux et al., 2002b) and has been discarded recently by Krom et al. (2010). $\mathrm{N}_{2}$ fixation was measured during the BOUM cruise and revealed only negligible fluxes in the eastern basin, but moderate fluxes in the western basin, with the highest rates measured in the Rhone river plume (Bonnet et al., 2011). The presence of both Hemiaulus hauckii and Rhizosolenia styliformis hosting Richelia intracellularis in the entire basin during both summer and fall as well as the presence of sporadic Trichodesmium sp. filaments could indicate that these species may play a larger role in $\mathrm{N}_{2}$ fixation at other periods of the year or that, for some reason, the sampling strategy for $\mathrm{N}_{2}$ fixation measurements do not allow to perform correct measurements. However, if we consider a functioning of these deep diatom summer blooms similar to that observed in the NPSG (Dore et al., 2008), the explanation to low $\mathrm{N}_{2}$ fixation rates, notably in the eastern basin, may very well lie in an extreme P-limitation. Diatoms potential contribution to $\mathrm{N}_{2}$ fixation in the western basin where fluxes are non negligible remains to be verified.

Concerning primary production in oligotrophic systems and as mentioned earlier in this paper, the diatom contribution should not be underestimated. Goldman (1988) first suggested that diatoms might be important for new production and export of particulate carbon in oligotrophic ocean gyres. They hypothesized that episodic injections of new nutrients near the base of the euphotic zone would lead to rapid diatom growth and a coupled enhanced export flux. However a more recent study evidenced that there was no need of episodic injections to maintain a balanced system in the permanently oligotrophic and stratified ocean (Riser and Johnson, 2008). In the oligotrophic Sargasso Sea, diatom contribution to primary production was as high as $26-48 \%$ and they contributed to $30 \%$ of the carbon export through the year (Brzezinski and Nelson, 1995; Nelson and Brzezinski, 1997). Other investigations carried out in the Central-North Pacific revealed that the siliceous phytoplankton can account for up to $25 \%$ of the primary productivity (Brzezinski et al., 1998). Diatom contribution to primary production is disproportionate compared to their relatively low contribution to TChl- $a$ biomass, which was for instance $<5 \%$ at BATS (Goericke, 1998; Steinberg et al., 2001). A similar situation was observed in the HNLC area of the Equatorial Pacific (Blain et al., 1997), where diatoms contribution to primary production was estimated to represent up to $34 \%$ despite a low contribution to $\mathrm{C}$ biomass $(<6 \%)$. Given these previous observations, we suggest that diatoms in the MS during the oligotrophic period may play a similar important role in the ecosystem productivity and contribute to a large part of new production and carbon export, despite their relatively low contribution to biomass during stratified conditions. This latter assumption can also be revised in the light of our present data on the recurrence of non negligible DSM in both the western and eastern basins, as far as in the ultra-oligotrophic Levantine basin. Furthermore, 
the concentrations of BSi found in these DSM were much higher than those found in the Sargasso Sea, the Equatorial or Central North Pacific in the studies cited above, which could also result in an even higher contribution of diatoms to $\mathrm{C}$ export. However, the mere fact that the DSM/DCM is a persistent feature in the MS implies that export rates remain low as long as this structure is present, or are otherwise compensated by higher productivity within the DCM. In this case, the contribution to export would be restrained to the onset of winter mixing and disruption of the stratified layer, which would then lead to an increased particulate matter flux at depth. However, if intense grazing upon the DCM is confirmed, potential higher $\mathrm{C}$ export from faecal pellets could already occur during late summer. Long-term immersion of sediment traps, as well as the deployment of biogeochemical and bio-optical Argo-like floats in open waters of the MS would help to test this hypothesis.

\section{Conclusions}

The Mediterranean pelagic ecosystem during summer and fall constitutes a large oligotrophic system characterized by a longitudinal gradient of stratification and nutrient depletion increasing towards the East. In this system, $\mathrm{N}$ and $\mathrm{P}$ appear to be the prominent limiting factors although $\mathrm{Si}$ could limit the growth of diatoms at some stations. The phytoplankton biomass is constrained within a deep chlorophyll maximum where organisms take benefit from the nutrient diffusive fluxes through the nutricline and sufficient light at the base of the euphotic layer. Considering the definition of phytoplankton bloom by Wilson (2003) as sustained Chl- $a$ values $>0.15 \mu \mathrm{g} \mathrm{L}^{-1}$, it would be adequate to characterise the MS as hosting a deep summer bloom that is not visible by satellite imagery and that would lead to modulate the characterization of the Eastern basin as a "non bloom" region as suggested by D'Ortenzio and Ribera d'Alcala (2009). Although usually thought to be dominated by pico- and nanophytoplankton, we show that this DCM can host an abundant diatom community as evidenced by the locally associated deep silica and fucoxanthin maxima as well as diatom counts. The dominant genera Chaetoceros, Pseudo-nitzschia, Thalassiosira, Hemiaulus, and Rhizosolenia as well as the $\mathrm{N}_{2}$-fixing symbionts Richelia intracellularis can take advantage of increasing nutrient fluxes probably modulated by mesoscale eddies controlling the successive deepening/shoaling of nutriclines. Under some circumstances, diatom growth in those oligotrophic systems and their ability to locally dominate the DCM community over nano- and picoplankton could profoundly affect the ecosystem, notably by increasing new production and carbon export as observed in other oligotrophic systems worldwide.

Thanks to the PROSOPE and BOUM cruises, large-scale data on the silicon cycle covering the whole Mediterranean Sea during the stratified period were obtained for the first time. There is now evidence that diatoms can actively develop at depth in one of the most oligotrophic systems of the World Ocean forming a "deep glass forest" in the MS during summer and fall. We suggest that these DSM are recurrent seasonal features, similar to those observed in the NPSG, although non permanent year round and that the contribution of diatoms harbouring cyanobacteria to $\mathrm{N}_{2}$ fixation needs to be further evaluated as these DSM have most likely been undersampled. Future studies are needed to investigate the contribution of these structures to the global MS productivity and to carbon export at depth as well as the role of physical submeso- to mesoscale processes on the formation and persistence of the DCM/DSM throughout the summer/fall thermal stratification.

Acknowledgements. We which to thank the captain and crew of the Thalassa and the Atalante oceanographic research vessels for their valuable help at sea. We would like to acknowledge the excellent work of Marie-Paule Torre for constituting the PROSOPE and BOUM websites and data archives. We acknowledge P. Raimbault for providing the POC data during the PROSOPE cruise and F. Gomez for providing diatom abundance and taxonomy data for both cruises. This work is a contribution to the "Souther European Seas: Assessing and Modelling Ecosystem Changes" (SESAME) which receives funding from the European Community's Sixth Framework Programme (FP6/2002-2006) under grant agreement 036949, to the PROSOPE project of the PROOF program of CNRS/INSU, and the BOUM project of the LEFE/CYBER program of CNRS/INSU. Finally we thank Damien Cardinal and an anonymous reviewer for greatly helping us improve the quality of this manuscript.

Edited by: A. V. Borges

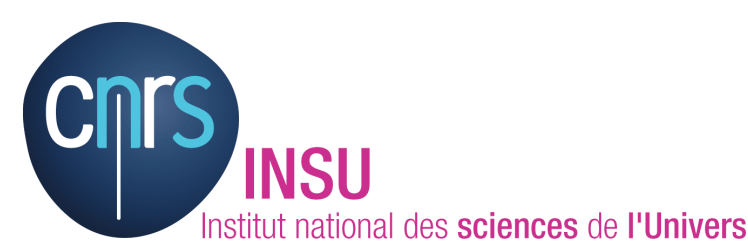

The publication of this article is financed by CNRS-INSU.

\section{References}

Abdel-Moati, A. R.: Particulate organic matter in the subsurface chlorophyll maximum layer of the southeastern Mediterranean., Oceanol. Acta, 13, 307-315, 1990.

Agusti, S., Satta, M. P., Mura, M. P., and Benavent, E.: Dissolved esterase activity as a tracer of phytoplankton lysis: Evidence of high phytoplankton lysis rates in the northwestern Mediterranean, Limnol. Oceanogr., 43, 1836-1849, 1998.

Azov, Y.: Eastern Mediterranean - a marine desert?, Mar. Pollut. Bull., 23, 225-232, 1991.

Benitez-Nelson, C. R., Bidigare, R. R., Dickey, T. D., Landry, M. R., Leonard, C. L., Brown, S. L., Nencioli, F., Rii, Y. M., Maiti, 
K., Becker, J. W., Bibby, T. S., Black, W., Cai, W.-J., Carlson, C. A., Chen, F., Kuwahara, V. S., Mahaffey, C., McAndrew, P. M., Quay, P. D., Rappe, M. S., Selph, K. E., Simmons, M. P., and Yang, E. J.: Mesoscale eddies drive increased silica export in the subtropical Pacific Ocean, Science, 316, 1017-1021, doi:10.1126/science.1136221, 2007.

Berman, T., Townsend, D. W., El Sayed, S. Z., Trees, C. C., and Azov, Y.: Optical transparency, chlorophyll and primary productivity in the eastern Mediterranean near the Israeli coast, Oceanol. Acta, 7, 367-372, 1984.

Béthoux, J. P., Morin, P., Madec, C., and Gentili, B.: Phosphorus and nitrogen behaviour in the Mediterranean Sea, Deep Sea Res. Pt. I, 39, 1641-1654, 1992.

Béthoux, J. P., Morin, P., Chaumery, C., Connan, O., Gentili, B., and Ruiz-Pino, D.: Nutrients in the Mediterranean Sea, mass balance and statistical analysis of concentrations with respect to environmental change, Mar. Chem., 63, 155-169, 1998.

Béthoux, J. P., Morin, P., and Ruiz-Pino, D. P.: Temporal trends in nutrient ratios: Chemical evidence of Mediterranean ecosystem changes driven by human activity, Deep-Sea Res. Pt. II, 49, 2007-2016, 2002a.

Béthoux, J. P., Durieu de Madron, X., Nyffeler, F., and Tailliez, D.: Deep water in the western Mediterranean: Peculiar 1999 and 2000 characteristics, shelf formation hypothesis, variability since 1970 and geochemical inferences, J. Mar. Sys., 33-34, 117-131, 2002 b.

Beucher, C., Tréguer, P., Hapette, A.-M., Corvaisier, R., Metzl, N., and Pichon, J.-J.: Intense summer Si-recycling in the surface Southern Ocean, Geophys. Res. Lett., 31, L09305, doi:10.1029/2003GL018998, 2004.

Blain, S., Leynaert, A., Tréguer, P., Chrétiennot-Dinet, M.-J., and Rodier, M.: Biomass, growth rates and limitation of Equatorial Pacific diatoms, Deep-Sea Res. Pt. I, 44, 1255-1275, 1997.

Bonnet, S., Grosso, O., and Moutin, T.: Planktonic dinitrogen fixation in the Mediterranean Sea: a major biogeochemical process during the stratified period?, Biogeosciences Discuss., 8, 1197 1225, doi:10.5194/bgd-8-1197-2011, 2011.

Brzezinski, M. A.: The Si:C:N ratios of marine diatoms : Interspecific variability and the effect of some environmental variables, J. Phycol., 21, 345-357, 1985.

Brzezinski, M. A. and Nelson, D. M.: The annual silica cycle in the Sargasso Sea near Bermuda, Deep-Sea Res. Pt. I, 42, 1215-1237, 1995.

Brzezinski, M. A. and Kosman, C. A.: Silica production in the Sargasso Sea during spring 1989, Mar. Ecol. Prog. Ser., 142, 39-45, 1996.

Brzezinski, M. A., Villareal, T. A., and Lipschultz, F.: Silica production and the contribution of diatoms to new and primary production in the central North Pacific, Mar. Ecol. Prog. Ser, 167, 89-104, 1998.

Carpenter, E. J., Montoya, J. P., Burns, J., Mulholland, M. R., Subramaniam, A., and Capone, D. G.: Extensive bloom of a $\mathrm{N}_{2}$-fixing diatom/cyanobacterial association in the tropical Atlantic Ocean, Mar. Ecol. Prog. Ser., 185, 273-283, doi:10.3354/meps 185273, 1999.

Claustre, H., Hooker, S. B., Van Heukelem, L., Berthon, J.-F., Barlow, R., Ras, J., Sessions, H., Targa, C., Thomas, C. S., van der Linde, D., and Marty, J.-C.: An intercomparison of HPLC phytoplankton pigment methods using in situ samples: Application to remote sensing and database activities, Mar. Chem., 85, 41-61, 2004.

Conte, M. H., Dickey, T. D., Weber, J. C., Johnson, R. J., and Knap, A. H.: Transient physical forcing of pulsed export of bioreactive material to the deep Sargasso Sea, Deep-Sea Res. Pt. I, 50, 1157 1187, 2003.

Crise, A., Allen, J. I., Baretta, J., Crispi, G., Mosetti, R., and Solidoro, C.: The Mediterranean pelagic ecosystem response to physical forcing., Prog. Oceanogr., 44, 219-243, 1999.

Crispi, G., Crise, A., and Solidoro, C.: Coupled Mediterranean ecomodel of the phosphorus and nitrogen cycles., J. Mar. Sys., 3334, 497-521, 2002.

D'Ortenzio, F. and Ribera d'Alcalá, M.: On the trophic regimes of the Mediterranean Sea: a satellite analysis, Biogeosciences, 6, 139-148, doi:10.5194/bg-6-139-2009, 2009.

Dore, J. E., Letelier, R. M., Church, M. J., Lukas, R., and Karl, D. M.: Summer phytoplankton blooms in the oligotrophic North Pacific subtropical gyre: Historical perspective and recent observations, Prog. Oceanogr., 76, 2-38, 2008.

Dugdale, R. C.: Nutrient cycles, in: The ecology of the sea, edited by: Cushing, D. H., Blackwell, 1976.

Ediger, D. and Yilmaz, A.: Characteristics of deep chlorophyll maximum in the northeastern Mediterranean with respect to environmental conditions, J. Mar. Sys., 9, 291-303, 1996.

Estrada, M.: Primary production at the deeep chlorophyll maximum in the western Mediterranean, 19th European Marine Biology Symposium (EMBS), 109-121, 1985.

Estrada, M., Marrasé, C., Latasa, M., Berdalet, E., Delgado, M., and Riera, T.: Variability of deep chlorophyll maximum characteristics in the northwestern Mediterranean MEPS, 92, 289-300, 1993.

Falkowski, P. G., Ziemann, D., Kolber, Z., and Bienfang, P. K.: Role of eddy pumping in enhancing primary production in the ocean, Nature, 352, 55-58, 1991.

Garcia, N., Raimbault, P., Gouze, E., and Sandroni, V.: Fixation de diazote et production primaire en Méditerranée occidentale, C. R. Biol., 329, 742-750, 2006.

Goericke, R.: Response of phytoplankton community structure and taxon specific growth rates to seasonally varying physical forcing in the sargasso sea off Bermuda, Limnol. Oceanogr., 43, 921935, 1998.

Goldman, J. C.: Spatial and temporal discontinuities of biological processes in pelagic surface waters, in: Toward a theory on biological-physical interactions in the world ocean, edited by: Rothschild, B. J., Kluwer Academic Publishers, Dordrecht, 1988.

Gould, R. W. and Wiesenburg, D. A.: Single-species dominance in a subsurface phytoplankton concentrationat a mediterranean sea front, Limnol. Oceanogr., 35, 211-220, 1990.

Guillard, R. R. L. and Kilham, P.: The ecology of marine planktonic diatoms, in: The biology of diatoms, edited by: Werner D., University of California Press, Berkeley, 1978.

Herut, B., Almogi-Labin, A., Jannink, N., and Gertman, I.: The seasonal dynamics of nutrient and chlorophyll a concentrations on the SE Mediterranean shelf-slope, Oceanol. Acta, 23, 771782, 2000.

Hooker, S. B., Van Heukelem, L., Thomas, C. S., Claustre, H., Ras, J., Schülter, L., Clementson, L., Van der Linde, D., EkerDeveli, E., Berthon, J.-F., Barlow, R., Sessions, H., Ismail, 
H., and Perl, J.: The third seawifs HPLC analysis round-robin experiment (seaharre-3), NASA Technical Memorandum 2009215849, 2009.

Hulburt, E. M.: Description of phytoplankton and nutrient in spring in the western North Atlantic Ocean, J. Plankton Res., 12, 1-28, doi:10.1093/plankt/12.1.1, 1990.

Ibello, V., Cantoni, C., Cozzi, S., and Civitarese, G.: First basin-wide experimental results on $\mathrm{N}_{2}$ fixation in the open Mediterranean Sea, Geophys. Res. Lett., 37, L03608, doi:10.1029/2009g1041635, 2010.

Ignatiades, L.: Annual cycle, species diversity and succession of phytoplankton in lower Saronicos Bay, Aegean Sea, Mar. Biol., 3, 196-200, 1969.

Jacques, G. and Tréguer, P.: Les écosystèmes pélagiques marins iii. L'océan antarctique, La Méditerranée occidentale, edited by: Tréguer, P. and Jacques, G., Masson, Paris, 255, 1986.

Kimor, B., Berman, T., and Schneller, A.: Phytoplankton assemblages in the deep chlorophyll maximum layers off the Mediterranean coast of Israel, J. Plankton Res., 9, 433-443, doi:10.1093/plankt/9.3.433, 1987.

Krause, J. W., Lomas, M. W., and Nelson, D. M.: Biogenic silica at the Bermuda Atlantic time-series study site in the Sargasso Sea: Temporal changes and their inferred controls based on a 15-year record, Global Biogeochem. Cycles, 23, GB3004, doi:10.1029/2008GB003236, 2009a.

Krause, J. W., Nelson, D. M., and Lomas, M. W.: Biogeochemical responses to late-winter storms in the Sargasso Sea, ii: Increased rates of biogenic silica production and export, Deep-Sea Res. Pt. I, 56, 861-874, 2009b.

Krom, M. D., Kress, N., and Brenner, S.: Phosphorus limitation of primary productivity in the eastern Mediterranean Sea, Limnol. Oceanogr., 36, 424-432, 1991.

Krom, M. D., Brenner, S., Kress, N., Neori, A., and Gordon, L. I.: Nutrient distributions during an annual cycle across a warmcore eddy from the E Mediterranean sea, Deep-Sea Res. Pt. I, 40, 805825,1993

Krom, M.: The oceanography of the eastern Mediterranean Sea, Ocean Challenge, 5, 22-28, 1995.

Krom, M. D., Herut, B., and Mantoura, R. F. C.: Nutrient budget for the eastern Mediterranean: Implications for phosphorus limitation, Limnol. Oceanogr., 49, 1582-1592, 2004.

Krom, M. D., Emeis, K. C., and Van Cappellen, P.: Why is the eastern Mediterranean phosphorus limited?, Prog. Oceanogr., 85, 236-244, 2010.

Leblanc, K., Quéguiner, B., Fiala, M., Blain, S., Morvan, J., and Corvaisier, R.: Particulate biogenic silica and carbon production rates and particulate matter distribution in the Indian sector of the Subantarctic Ocean, Deep-Sea Res. Pt. II, 49, 3189-3206, 2002.

Leblanc, K., Quéguiner, B., Prieur, L., Claustre, H., Oubelkheir, K., and Bruyant, F.: Siliceous phytoplankton production and export related to trans-frontal dynamics of the Almeria-Oran frontal system (western Mediterranean Sea) during winter, J. Geophys. Res.-Oceans, 109, doi:10.1029/2003JC001878, 2004.

Mann, K. H. and Lazier, J. R. N.: Dynamics of marine ecosystems: biological-physical interactions in the oceans, Blackwell Science, Oxford, 1996.

Martin-Jézéquel, V., Hildebrand, M., and Brzezinski, M.: Silicon metabolism in diatoms: Implications for growth, J. Phycol., 36, $821-840,2000$
McGill, D. A.: A preliminary study of the oxygen and phosphate distribution in the Mediterranean Sea, Deep Sea Res. 8, 259-268, doi:10.1016/0146-6313(61)90027-2, 1961.

McGill, D. A.: A budget for dissolved salts in the mediterranean sea, Cah. Oceanogr., 21, 543-554, 1969.

McGillicuddy, D. J. and Robinson, A. R.: Eddy-induced nutrient supply and new production in the Sargasso Sea, Deep-Sea Res. Pt. I, 44, 1427-1450, 1997.

McGillicuddy Jr., D. J., Anderson, L. A., Bates, N. R., Bibby, T., Buesseler, K. O., Carlson, C. A., Davis, C. S., Ewart, C., Falkowski, P. G., Goldthwait, S. A., Hansell, D. A., Jenkins, W. J., Johnson, R., Kosnyrev, V. K., Ledwell, J. R., Li, Q. P., Siegel, D. A., and Steinberg, D. K.: Eddy/wind interactions stimulate extraordinary mid-ocean plankton blooms, Science, 316, 10211026, doi:10.1126/science.1136256, 2007.

McNeil, J. D., Jannasch, H. W., Dickey, T., McGillicuddy, D., Brzezinski, M., and Sakamoto, C. M.: New chemical, bio-optical and physical observations of upper ocean response to the passage of a mesoscale eddy off Bermuda, J. Geophys. Res., 104, 1553715548, 1999.

Moran, X. A. G., Taupier-Letage, I., Vázquez-Domínguez, E., Ruiz, S., Arin, L., Raimbault, P., and Estrada, M.: Physical-biological coupling in the Algerian basin (SW Mediterranean): Influence of mesoscale instabilities on the biomass and production of phytoplankton and bacterioplankton, Deep-Sea Res. Pt. I, 48, 405437, 2001.

Morel, A. and Maritorena, S.: Bio-optical properties of oceanic waters: A reappraisal, J. Geophys. Res., 106(C4), 7163-7180, 2001.

Mosseri, J., Quéguiner, B., Armand, L., and Cornet-Barthaux, V.: Impact of iron on silicon utilization by diatoms in the Southern Ocean: A case study of $\mathrm{Si} / \mathrm{N}$ cycle decoupling in a naturally ironenriched area, Deep-Sea Res. Pt. II, 55, 801-819, 2008.

Moutin, T., Raimbault, P., Golterman, H. L., and Coste, B.: The input of nutrients by the Rhône river into the Mediterranean Sea : Recent observations and comparison with earlier data, Hydrobiologia, 373/374, 237-246, 1998.

Moutin, T. and Raimbault, P.: Primary production, carbon export and nutrients availability in western and eastern Mediterranean Sea in early summer 1996 (minos cruise), J. Mar. Sys., 33-34, 273-288, 2002.

Moutin, T., Thingstad, T. F., Van Wambeke, F., Marie, D., Slawyk, G., Raimbault, P., and Claustre, H.: Does competition for nanomolar phosphate supply explain the predominance of the cyanobacterium synechococcus?, Limnol. Oceanogr., 47, 15621567, 2002.

Moutin, T., Van Wambeke, F., and Prieur, L.: Introduction to the Biogeochemistry from the Oligotrophic to the Ultraoligotrophic Mediterranean (BOUM) experiment, Biogeosciences Discuss., in preparation, 2011.

Mullin, J. B. and Riley, J. P.: A modified single solution method for determination of phosphate in natural waters, Anal. Chim. Acta, 27, 31-36, 1962.

Nelson, D. M., Smith, W. O., Muench, R. D., Gordon, L. I., Sullivan, C. W., and Husby, D. M.: Particulate matter and nutrient distributions in the ice-edge zone of the Weddell Sea: Relationship to hydrography during late summer, Deep-Sea Res., 36, 191-209, 1989.

Nelson, D. M., Tréguer, M. A., Brzezinski, M. A., Leynaert, A., and Quéguiner, B.: Production and dissolution of biogenic silica 
in the ocean: Revised global estimates, comparison with regional data and relationship to biogenic sedimentation, Global Biogeochem. Cycle, 9, 359-372, 1995.

Nelson, D. M. and Brzezinski, M. A.: Diatom growth and productivity in an oligotrophic midocean gyre: A 3-yr record from the Sargasso Sea near Bermuda, Limnol. Oceanogr., 42, 473-486, 1997.

Parslow, J. S., Boyd, P. W., Rintoul, S. R., and Griffiths, F. B.: A persistent subsurface chlorophyll maximum in the interpolar frontal zone South of Australia: Seasonal progression and implications for phytoplankton-light-nutrient interactions, J. Geophys. Res., 106, C12, doi:10.1029/2000JC000322, 2001.

Perkins, H., Kinder, T., and La Violette, P.: The Atlantic inflow in the western Alboran Sea, J. Phys. Oceanogr., 20(2), 242-263, 1990.

Price, N. B., Lindsay, F. S., and Pates, J. M.: The biogeochemistry of major elements of the suspended particulate matter of the cretan sea, Prog. Oceanogr., 44, 677-699, 1999a.

Price, N. B., Brand, T., Pates, J. M., Mowbray, S., Theocharis, A., Civitarese, G., Miserocchi, S., Heussner, S., and Lindsay, F.: Horizontal distributions of biogenic and lithogenic elements of suspended particulate matter in the Mediterranean Sea, Prog. Oceanogr., 44, 191-218, 1999b.

Pujo-Pay, M., Conan, P., Oriol, L., Cornet-Barthaux, V., Falco, C., Ghiglione, J.-F., Goyet, C., Moutin, T., and Prieur, L.: Integrated survey of elemental stoichiometry $(\mathrm{C}, \mathrm{N}, \mathrm{P})$ from the Western to Eastern Mediterranean Sea, Biogeosciences Discuss., 7, 73157358, doi:10.5194/bgd-7-7315-2010, 2010.

Quéguiner, B.: Biogenic silica production in the Australian sector of the Subantarctic zone of the Southern Ocean in late summer 1998, J. Geophys. Res., 106, C12, doi:10.1029/2000JC000249, 2001.

Quéguiner, B. and Brzezinski, M. A.: Biogenic silica production rates and particulate organic matter distribution in the Atlantic sector of the Southern Ocean during austral spring 1992, DeepSea Res. Pt. II, 49, 1765-1786, 2002.

Raimbault, P., Diaz, F., Pouvesle, W., and Boudjellal, B.: Simultaneous determination of particulate organic carbon, nitrogen and phosphorus collected on filters, using a semi-automatic wet-oxidation method, Mar. Ecol. Prog. Ser., 180, 289-295, doi:10.3354/meps 180289, 1999.

Ras, J., Claustre, H., and Uitz, J.: Spatial variability of phytoplankton pigment distributions in the Subtropical South Pacific Ocean: comparison between in situ and predicted data, Biogeosciences, 5, 353-369, doi:10.5194/bg-5-353-2008, 2008.

Redfield, A. C., Ketchum, B. H., and Richards, F. A.: The influence of organisms on the composition of sea water, in: The sea, ideas and observations on progress in the study of the seas, edited by: Hill, M. N., Interscience publ., NY, 1963.

Ribera d'Alcala, M., Civitarese,G., Conversano, F., Lavezza, R.: Nutrient ratios and fluxes hint at overlooked processes in the Mediterranean Sea, J. Geophys. Res, 108, 8106, 16 pp, 2003.

Riley, G. A.: Phytoplankton of the North central Sargasso Sea, 1950-52, Limnol. Oceanogr., 2, 252-270, 1957.

Riser, S. C. and Johnson, K. S.: Net production of oxygen in the Subtropical ocean, Nature, 451, 323-325, 2008.

Ryan, W. B. F.: Mediterranean Sea: Physical oceanography. In: The encyclopedia of oceanography, edited by: Fairbridge, R. W., Van Nostrand and Reinhold, 1966.
Sachs, J. P. and Repeta, D. J.: Oligotrophy and nitrogen fixation during eastern Mediterranean sapropel events, Science, 286, 24852488, doi:10.1126/science.286.5449.2485, 1999.

Scharek, R., Latasa, M., Karl, D. M., and Bidigare, R. R.: Temporal variations in diatom abundance and downward vertical flux in the oligotrophic North Pacific gyre, Deep-Sea Res. Pt. I, 46, 1051$1075,1999$.

Siokou-Frangou, I., Christaki, U., Mazzocchi, M. G., Montresor, M., Ribera d'Alcalá, M., Vaqué, D., and Zingone, A.: Plankton in the open Mediterranean Sea: a review, Biogeosciences, 7, 1543-1586, doi:10.5194/bg-7-1543-2010, 2010.

Sournia, A.: La production primaire planctonique en Méditerranée, Newsl. Coop. Invest. Mediterr. Spec., 128, 1973.

Steinberg, D. K., Carlson, C. A., Bates, N. R., Johnson, R. J., Michaels, A. F., and Knap, A. H.: Overview of the US JGOFS Bermuda Atlantic time-series study (BATS): A decade-scale look at ocean biology and biogeochemistry, Deep-Sea Res. Pt. II, 48, 1405-1447, 2001.

Strickland, J. D. H. and Parsons, T. R.: A practical handbook of seawater analysis, Fisheries Research Board of Canada Bulletin, 167, 310, 1972.

Tanaka, T., Thingstad, T. F., Christaki, U., Colombet, J., CornetBarthaux, V., Courties, C., Grattepanche, J.-D., Lagaria, A., Nedoma, J., Oriol, L., Psarra, S., Pujo-Pay, M., and Van Wambeke, F.: N-limited or $\mathrm{N}$ and $\mathrm{P}$ co-limited indications in the surface waters of three Mediterranean basins, Biogeosciences Discuss., 7, 8143-8176, doi:10.5194/bgd-7-8143-2010, 2010.

Taupier-Letage, I., Puillat, I., Millot, C., and Raimbault, P.: Biological response to mesoscale eddies in the Algerian basin, J. Geophys. Res., 108, 3245, doi:10.1029/1999jc000117, 2003.

Theodorou, A., Theocharis, A., and Balopoulos, E.: Circulation in the Cretan Sea and adjacent regions in late winter 1994, Oceanol. Acta, 20, 585-596, 1997.

Thingstad, T. F. and Rassoulzadegan, F.: Nutrient limitations, microbial food webs, and biological C-pump : Suggested interactions in a P-limited Mediterranean., Mar. Ecol. Prog. Ser., 117, 299-306, 1995.

Tréguer, P. and Le Corre, P.: Manuel d'analyses des sels nutritifs dans l'eau de mer. Utilisation de l'auto analyzer technicon, Laboratoire d'Océanographie Chimique, U.B.O., Brest, 1975.

Tréguer, P., Nelson, D. M., Van Bennekom, A. J., DeMaster, D. J., Leynaert, A., and Quéguiner, B.: The silica balance in the world ocean: A reestimate, Science, 268, 375-379, 1995.

Tselepides, A., Zervakis, V., Polychronaki, T., Danovaro, R., and Chronis, G.: Distribution of nutrients and particulate organic matter in relation to the prevailing hydrographic features of the Cretan Sea (NE Mediterranean), Prog. Oceanogr., 46, 113-142, 2000.

Uitz, J., Claustre, H., Gentili, B., and Stramski, D.: Phytoplankton class-specific primary production in the world's oceans: Seasonal and interannual variability from satellite observations, Global Biogeochem. Cycles, doi:10.1029/2009GB003680, 2010.

Vidussi, F., Claustre, H., Bustillos-Guzman, J., Cailliau, C., and Marty, J.-C.: Determination of chlorophylls and carotenoids of marine phytoplankton: Separation of chlorophyll a from divinylchlorophyll a and zeaxanthin from lutein, J. Plankton Res., 18, 2377-2382, doi:10.1093/plankt/18.12.2377, 1996.

Vidussi, F., Marty, J.-C., and Chiavérini, J.: Phytoplankton pigment variations during the transition from spring bloom to oligotrophy 
in the northwestern Mediterranean Sea, Deep-Sea Res. Pt. I, 47, 423-445, 2000.

Villareal, T. A.: Nitrogen-fixation by the cyanobacterial symbiont of the diatom genus Hemiaulus, Mar. Ecol. Prog. Ser., 76, 201204, 1991.

Villareal, T. A., Pilskaln, C., Brzezinski, M., Lipschultz, F., Dennett, M., and Gardner, G. B.: Upward transport of oceanic nitrate by migrating diatoms mats, Nature, 397, 423-425, 1999.
Wilson, C.: Late summer chlorophyll blooms in the oligotrophic North Pacific Subtropical gyre, Geophys. Res. Lett., 30, 1942, doi:10.1029/2003GL017770, 2003.

Zohary, T., Brenner, S., Krom, M. D., Angel, D. L., Kress, N., Li, W. K. W., Neori, A., and Yacobi, Y. Z.: Buildup of microbial biomass during deep winter mixing in a Mediterranean warm-core eddy, Mar. Ecol. Prog. Ser., 167, 47-57, doi:10.3354/meps 167047, 1998. 